\title{
Peripheral immune system in aging and Alzheimer's disease
}

\author{
Wei Cao ${ }^{*}$ and Hui Zheng ${ }^{*}$ (1)
}

\begin{abstract}
Alzheimer's disease (AD) represents an urgent public health mandate. AD is no longer considered a neural-centric disease; rather, a plethora of recent studies strongly implicate a critical role played by neuroinflammation in the pathogeneses of $\mathrm{AD}$ and other neurodegenerative conditions. A close functional connection between the immune system and central nervous system is increasingly recognized. In late-onset $A D$, aging represents the most significant risk factor. Here, from an immunological perspective, we summarize the prominent molecular and cellular changes in the periphery of aging individuals and AD patients. Moreover, we review the knowledge gained in the past several years that implicate specific arms of the peripheral immune system and other types of immune responses in modulating AD progression. Taken together, these findings collectively emphasize a dynamic role of a concert of brain-extrinsic, peripheral signals in the aging and degenerative processes in the CNS. We believe that a systematic view synthesizing the vast amounts of existing results will help guide the development of next-generation therapeutics and inform future directions of $A D$ investigation.
\end{abstract}

Keywords: Alzheimer's disease, Aging, Senescence, Peripheral immune response, Adaptive immune response, Humoral immune response, T cells, T regulatory cells, Immunosignature

\section{Background}

Alzheimer's disease (AD), the most common form of age-associated dementia and neurodegenerative disorder, is a major public health predicament and represents a fundamental scientific challenge. Traditionally, AD has been viewed as a brain-specific disease. Pathologically, AD brains harbor amyloid plaques that contain extracellularly deposited amyloid $\beta$ (A $\beta$ ) from cleaved amyloid precursor protein, and neurofibrillary tangles formed by intracellular accumulation of hyperphosphorylated and misfolded tau protein. These characteristic entities inspired a leading theory that centers on the loss of proteostasis within the brain, which instigates the pathogenic course of AD. The Amyloid Cascade Hypothesis [1-3] has guided numerous studies in the past two decades, which helped reveal insights of the neuronal properties and pathological events initiated by $A \beta$ and subsequently by tau aggregation. However, it is clear that late-onset Alzheimer's disease (LOAD) is collectively modified by numerous genetic factors that govern

\footnotetext{
* Correspondence: wei.cao@bcm.edu; huiz@bcm.edu

Department of Molecular and Human Genetics, Baylor College of Medicine, Huffington Center on Aging, Houston, TX 77030, USA
}

diverse cellular and molecular pathways, including many genes involved in the immune responses [4-6]. Consequently, The Neuroinflammation Hypothesis emphasizes the dysregulation of central nervous system (CNS) immune response as a key factor in the etiology of neurodegenerative diseases. In recent years, neuroinflammation is increasingly recognized as an integral and critical contributor in AD pathogenesis [7-9].

The role played by the immune system in $\mathrm{AD}$ pathogenesis is prominent but is by no means limited to the brain. Copious evidence from clinical and experimental research suggests an influential, yet largely underappreciated, force in $\mathrm{AD}$ pathogenesis: systemic immune signals originating outside the brain. This review will primarily focus on the changes and involvement of the peripheral immune system in aging and AD. Readers interested in the functions of microglia, brain-resident macrophage-like immune cells at the center of neuroinflammation, in aging and $\mathrm{AD}$ can refer to other recent publications [10-15]. Here we summarize the current understanding of the profound effects of aging on the systemic components of the host. We further review how different elements of the peripheral immune system

(c) The Author(s). 2018, corrected publication November/2018. Open Access This article is distributed under the terms of the Creative Commons Attribution 4.0 International License (http://creativecommons.org/licenses/by/4.0/), which permits

unrestricted use, distribution, and reproduction in any medium, provided you give appropriate credit to the original author(s) and the source, provide a link to the Creative Commons license, and indicate if changes were made. The Creative Commons Public Domain Dedication waiver (http://creativecommons.org/publicdomain/zero/1.0/) applies to the data made available in this article, unless otherwise stated. 
and diverse responses modulate the functions of the brain, influence neuroinflammation, and participate in $\mathrm{AD}$ pathogenesis with a focus on $\mathrm{A} \beta$-associated events, and discuss implications in the therapeutic development for AD. By uniting multiple influential processes and bridging cross-disciplinary studies, we present a unique systematic perspective to broaden the comprehension on the molecular and cellular players involved in $\mathrm{AD}$ pathogenesis.

\section{Systemic changes associated with aging Inflammaging}

As the most significant risk factor for AD, aging itself exerts profound impacts on the immune system and the peripheral tissues (Fig. 1). Innate immunity protects the host by detecting pathogen-associated pattern molecules and activating signaling pathways that result in rapid secretion of cytokines and chemokines, the key soluble immune effector molecules. It has been shown that aging alters the components of innate immunity ranging from the expression of signaling molecules to the behavior of neutrophils, monocytes, dendritic cells, NK cells, etc. [16]. The phenomenon of inflammaging is characterized by chronic low-grade inflammation and functional decline in an aging host $[17,18]$. Inflammasomes are intracellular multicomponent structures that enable the secretion of IL-1 $\beta$ and IL-18, important proinflammatory cytokines $[19,20]$. The expression of specific inflammasome gene modules in older individuals is associated with higher incidence of elevated blood pressure, arterial stiffness, metabolic dysfunction, oxidative stress and shortened life span [21]. Accordingly, age-related increase in circulating IL-18 is significantly reduced in mice lacking Nlrp3 inflammasome or inflammasome adaptor Asc [22]. Other cytokines and proinflammatory factors have also been associated with age-related decline in physical and cognitive function [23, 24].

\section{Immune cell skewing}

Aging is associated with increased cell-to-cell transcriptional variability in different tissues, including cells of the hematopoietic lineage [25-28]. Accordingly, aged peripheral immune cells contain highly heterogeneous epigenetic modifications between individuals and from cell to cell, as revealed by single-cell chromatin modification profiling [28]. In addition, substantial alteration in the populations of cells mediating adaptive immunity is well-documented: naïve $\mathrm{T}$ cells and circulating B cells are reduced while terminally differentiated $\mathrm{T}$ cells are increased in aged individuals $[16,29]$. The age-dependent loss of $\mathrm{T}$ cell homeostasis has been linked to thymus involution, which is mediated by Nlrp3 inflammasome [22]. Aged naïve $\mathrm{T}$ cells possess a less diverse $\mathrm{T}$ cell receptor (TCR) repertoire and may switch to a dysfunctional "virtual memory" cell phenotype, which is accompanied by profound epigenetic changes [28-34]. Furthermore, both aged $\mathrm{CD}_{4}^{+}$and $\mathrm{CD}^{+} \mathrm{T}$ cells display features of cellular senescence (see below). In aging, $B$ cell receptor repertoire diversity and switched memory B cells are significantly reduced, which is accompanied by a diminished antibody response to antigen challenge. On the other hand, a distinct subset of mature B cells, termed age-associated B cells, accumulates in aged mice and older humans, which may promote inflammation and autoimmunity while inhibiting B cell lymphopoiesis [35, 36]. Beyond blood, aging shifts the functional balance between self-renewal and differentiation in hematopoietic stem cells in the bone marrow and favors the generation of myeloid lineage cells [37]. Overall, an aged immune system renders the host susceptible to infections and

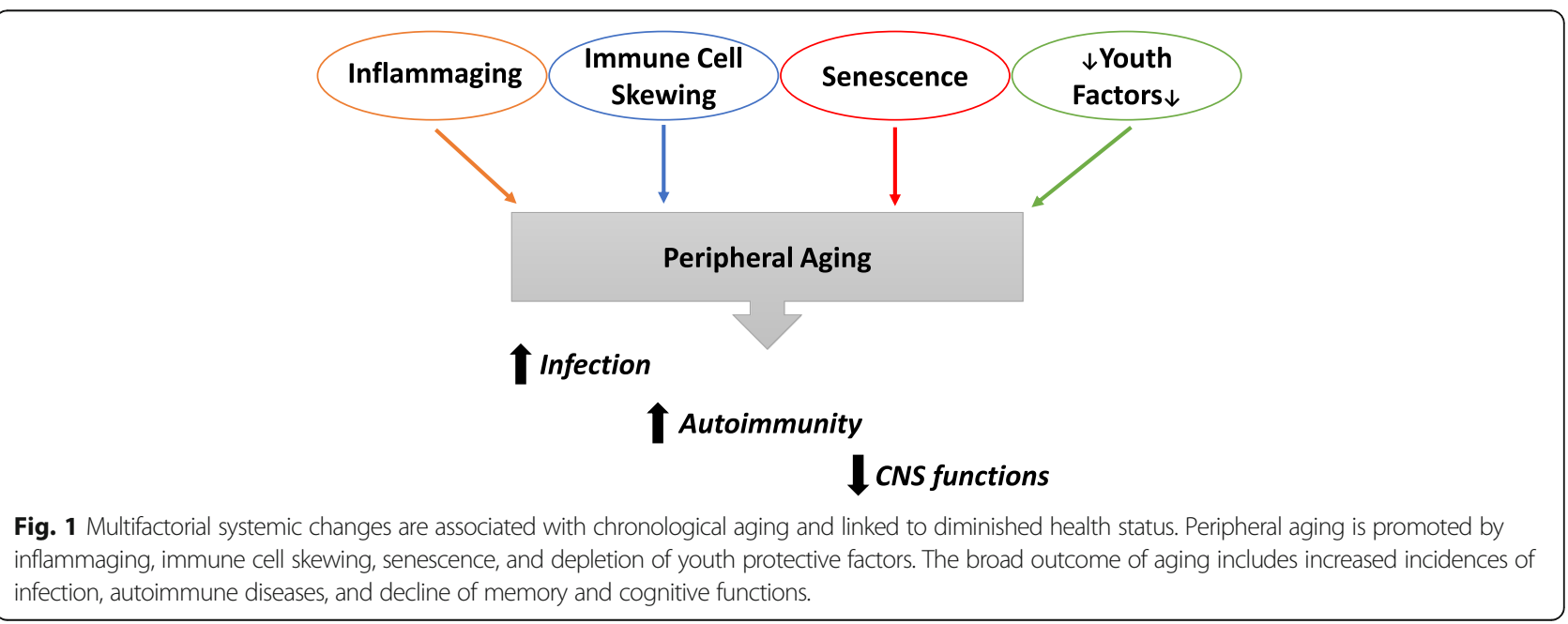


increases the incidences of autoimmune and other diseases, which is accompanied by the decline of cognitive functions (Fig. 1).

\section{Senescence}

During aging, senescent cells accumulate in the body by entering a long-lasting form of cell-cycle arrest triggered by various molecular stressors. Breakthrough studies in recent years have revealed a complex mechanism underlying the biogenesis of these cells and their roles in diverse physiological and pathological conditions (reviewed in [38-40]). The involvement of senescent cells in host immunity is closely linked to their acquired ability to secrete proinflammatory cytokines, a phenomenon termed the senescence-associated secretory phenotype (SASP) [18]. SASP is induced primarily by NF- $\mathrm{kB}$ in response to DNA damage, oncogenic stress and developmental cues, which initiates the transcription of a host of genes including IL-6, IL-1 $\beta$, TNF- $\alpha$, IL-8, etc. [41, 42]. Given the proinflammatory nature of SASP, cellular senescence in multiple organs and tissues significantly promotes inflammaging in the elderly $[18,43]$. As mentioned earlier, naïve $\mathrm{T}$ cell senescence is associated with a loss of immune diversity. Concomitantly, terminally differentiated senescent $\mathrm{T}$ cells expand and over-express cytotoxins and proinflammatory cytokines, contributing to the hyperinflammatory status of the host. Several groups recently demonstrated a remarkable functional restoration in multiple tissues and organs of the mice after selective ablation of senescent cells by genetic manipulation or treatment with senolytic compounds [44]. The classical senescent cells have not been widely identified in aging CNS beyond the description of SASP+ astrocytes [45]. The impact of senescent cell ablation on brain function is yet to be demonstrated.

\section{Diminished youth factors}

Aging not only induces the generation of harmful products, it also depletes the molecules that keep the host young [46]. Shared circulation between young and old mice by way of parabiosis has demonstrated the ability of old blood to transfer aging phenotypes to peripheral tissues and the brain of young mice, and vice versa [47]. Immune factors enriched in aged plasma, such as CCL11 and B2M, have been shown to negatively affect neurogenesis and memory $[47,48]$. In contrast, growth and differentiation factor 11 (GDF-11) supplementation to aged mice was shown to benefit the heart and muscle and increase neurogenesis [49-51]. However, the expression and function of GDF-11 remains controversial and further studies are needed to confirm its role in host rejuvenation [52, 53]. Nevertheless, a proof-of-concept study demonstrated a near complete restoration of synaptic and neuronal proteins in aged amyloid precursor protein (APP)-expressing mice after exposure to circulating young blood or receiving plasma transfusion [54]. Improved working and associative memory occurred after young plasma administration in the absence of changes in amyloid load [54]. A renewed search for systemic brain rejuvenating factors led to the recent identification of tissue inhibitor of metalloproteases 2 (TIMP2), which is present at highest levels in the human umbilical cord blood, over young and old adult blood [55]. As reported, TIMP2 not only promotes neuronal plasticity inside the brain likely through modulating extracellular matrix, but also affects hippocampal synaptic plasticity from systemic circulation. Although direct translation of the findings to human diseases is uncertain at this point, these studies illustrate a dynamic, complex, and powerful crosstalk between the periphery and the brain.

\section{Molecular alterations in the circulation of $A D$ patients}

Early observational studies and meta-analyses detected an association between elevated levels of inflammatory factors and increased risk for AD development $[56,57]$. In the past decade, many proteomic surveys have been performed mostly on human plasma and occasionally on serum samples, using diverse technical platforms, ranging from filter-based arrayed sandwich ELISA, 2D-gel electrophoresis coupled with liquid chromatography and mass spectrometry, Luminex xMAP, Myriad RBM, to SOMAscan multiplexed protein technology (reviewed in $[51,58])$. Although the list of top altered proteins overlapped and differed between individual studies, a consensus pathway analysis revealed significant changes of multiple immunological processes, among which Complement and Coagulation Cascades and Cytokine-Cytokine Receptor Interaction are ominously affected [58]. Noteworthy is that both are centrally involved in the neuroinflammation inside the brains of $\mathrm{AD}$ patients and $\mathrm{AD}$ animal models [59, 60].

Although over $20 \%$ of people diagnosed with mild cognitive impairment (MCI) develop dementia over the subsequent 3 to 10 years, it remains difficult to predict the disease course for individual patients. By examining the plasma communicome, i.e. a group of signaling proteins involved in intracellular communication, Ray et al reported an initial success in identifying MCI patients who are en route to develop AD based on a panel of 18 affected proteins consisting primarily of chemokines and growth factors [61]. Subsequent studies using more advanced detection technologies and analyzing a larger cohort of patients established a subset of 10-13 plasma proteins, including several apolipoproteins, chemokines and growth factors, whose abundance is associated with disease severity and progression of $\mathrm{AD}[62,63]$. More 
recently, a simple combination of two plasma markers (Apo A-II and cortisol) and four cerebrospinal fluid (CSF) proteins (fibroblast growth factor 4, calcitonin, heart-type fatty acid binding protein, and TRAIL-R3) was shown to be valuable in predicting midterm progression from MCI to AD dementia [64]. Hence, molecular changes in the blood may be useful to probe the ongoing neurodegeneration in the brain. Before any of these markers are adopted as blood biomarkers for clinical prognosis, their robustness, accuracy, and reproducibility need to be firmly established.

\section{Involvement of peripheral immune cells in brain homeostasis and aging}

Like other organs, the CNS is under regular immune surveillance. While microglia cells reside inside the parenchyma, small but significant numbers of $\mathrm{T}$ cells, $\mathrm{B}$ cells, NK cells, and dendritic cells migrate into and populate the meninges and choroid plexus $(\mathrm{CP})$ that form a direct interface with the brain parenchyma [65]. A series of studies have established an indispensable role played by $\mathrm{CD} 4^{+} \mathrm{T}$ cells in maintaining the cognitive and behavioral capacity of naive mice [66-68]. In particular, $\mathrm{CD}_{4}^{+} \mathrm{T}$ helper cells and their secreted cytokines after undergoing polarization facilitate memory function and social behaviors. Both IFNy-producing $\left(\mathrm{T}_{\mathrm{H}} 1\right)$ and IL-4-producing $\left(\mathrm{T}_{\mathrm{H}} 2\right) \mathrm{CD} 4^{+} \mathrm{T}$ cells reside in the meninges under steady-state conditions. IFN $\gamma$ supports neuronal circuits that are important for social behavior [69] and IL-4 facilitates learning by regulating meningeal dendritic cells and stimulating BDNF expression in astrocytes [70]. Therefore, $\mathrm{T}$ cells and their secreted cytokines are critically involved in preserving the homeostatic functions of the brain (Table 1).

$\mathrm{CP}$ is an epithelial tissue located within the ventricles of the brain [71, 72]. As the site of the blood-CSF barrier, $\mathrm{CP}$ plays indispensable roles in maintaining brain homeostasis by secreting neurotropic factors into CSF, clearing toxic molecules including $A \beta$ from CSF, and facilitating immune surveillance and leukocyte trafficking $[71,72]$. In naïve mice, more than $50 \%$ of $C D 4^{+}$and $\mathrm{CD}^{+} \mathrm{T}$ cells in the brain reside in the stroma of the $\mathrm{CP}$. Most of these $\mathrm{T}$ cells have an effector memory phenotype, including $\mathrm{T}_{\mathrm{H}} 1, \mathrm{~T}_{\mathrm{H}} 2$ and Tregs, and recognize CNS antigens [73]. However in aged $\mathrm{CP}$, a distorted $\mathrm{T}_{\mathrm{H}} 1 \mathrm{~T}_{\mathrm{H}} 2$ balance arises, which results in increased chemokine CCL11 expression, decreased permeability to leukocytes owing to the differential effects of IL-4 and IFNy on CP epithelial cells, and compromised cognition [73-75] (Table 1). Type I interferon (IFN-I) is a major innate immune cytokine commonly involved in host defense as well as autoimmune conditions. Interestingly, aged CP of both human and mouse display strong IFN-I signaling, which was shown to counter the function of IFN $\gamma$ (i.e. type II interferon), disrupt the infiltration of monocytes, and hamper cognitive functions and hippocampal neurogenesis [76]. Hence, aging disrupts the balance of brain-homing peripheral immune cells, which negatively impacts essential CNS functions.

\section{Involvement of peripheral immune cells in AD pathogenesis \\ Innate immune cells}

Inside the brain, ongoing $\mathrm{AD}$ pathology leads to the differentiation of microglia into a novel type associated with neurodegenerative diseases with altered molecular expression profile and limited phagocytic capacity $[77,78]$. The precise origin of plaque-surrounding amoeboid myeloid cells has long been debated, owing to the technical challenge of distinguishing infiltrating myeloid cells from locally-activated microglia. Nevertheless, recent evidence suggests that peripherally-derived macrophages can engraft the brain and maintain a unique functional and transcriptional identity in CNS [79]. Infiltrating peripheral myeloid cells have been demonstrated to participate in $A \beta$ clearance, leading to the notion that monocytes are superior phagocytes when traversed inside the AD brain [80, 81]. However, such a conclusion is challenged by studies showing that infiltrating peripheral myeloid cells, in replacing ablated microglia, adopt a microglia-like phenotype in the brain, i.e. with limited phagocytic capacity, likely influenced by local molecular cues $[82,83]$. Whether additional signals are needed to boost their phagocytic function in situ requires further investigation.

Rare variants in Triggering Receptor Expressed on Myeloid cells 2 (TREM2) increase the risk of developing $\mathrm{AD}$ by $2 \sim 3$ fold. Significant TREM2-dependent

Table $1 \mathrm{~T}$ cell subsets maintain homeostatic brain functions

\begin{tabular}{|c|c|c|c|c|c|}
\hline $\begin{array}{l}\text { Subset/ } \\
\text { Cytokine }\end{array}$ & Location & $\begin{array}{l}\text { Effects on } \\
\text { brain function }\end{array}$ & Specificity & Mechanism & Reference \\
\hline $\mathrm{T}_{H} 1 / \mathrm{IFN} \mathrm{N}_{\gamma}$ & Meninges & $\uparrow$ Social behavior & bulk & $\begin{array}{l}\text { IFNy signaling activation in inhibitory neurons } \\
\text { increases GABAergic currents }\end{array}$ & [69] \\
\hline $\mathrm{T}_{\mathrm{H}} 2 / \mathrm{IL}-4$ & Meninges & $\uparrow$ Learning and memory & bulk & $\begin{array}{l}\text { Restricts meningeal myeloid cell activation and } \\
\text { promotes neutrophic factor expression }\end{array}$ & {$[70]$} \\
\hline$\uparrow T_{H} 2: T_{H} 1$ ratio & CP of Aged Mice & $\downarrow$ Cognitive capacity & CNS antigens & $\begin{array}{l}\text { IL-4 induces while IFNy inhibits CCL11 expression } \\
\text { by epithelia cells }\end{array}$ & {$[73]$} \\
\hline
\end{tabular}


phenotypes in mouse models of $\mathrm{AD}$ shed light on the role of TREM2 in regulating neuroinflammation during AD pathogenesis [84]. Besides CNS upregulation, expression of TREM2 mRNA and protein are increased in the peripheral leukocytes of $\mathrm{AD}$ patients and correlated with cognitive deficits and hippocampal atrophy [85-88]. It is unclear if elevated peripheral TREM2 expression has functional impact on disease pathogenesis or merely reflects the ongoing systemic inflammation of $\mathrm{AD}$.

Neutrophils are the most abundant myeloid cells in human peripheral blood and participate critically in protective innate immunity. Neutrophils have been detected in the brain parenchyma of $5 x F A D$ and $3 x T g-A D$ mice and were shown to promote amyloid plaques and tau tangles as well as cognitive decline [89]. Yet, a separate study showed that long term treatment of 3xTg-AD mice with a TNF- $\alpha$ modulator led to increased neutrophil infiltration in the brain, which coincided with improved learning and memory, and reduced tau and amyloid pathology [90]. Thus, the functional features of infiltrating neutrophils remain to be fully elucidated.

\section{Adaptive immune cells}

Distinct from innate immunity, adaptive immune responses protect the host in a manner that is long-lasting and antigen-specific. Although innate immune responses at the site of brain inflammation are well-established, the role played by adaptive immunity in $\mathrm{AD}$ remains vague, primarily due to the scarcity of $\mathrm{T}$ cells or B cells inside the parenchyma. Nevertheless, a recent large-scale genome-wide association study strongly implicated the involvement of both adaptive and innate immunity in $\mathrm{AD}$ [91]. In addition, the association of a single-nucleotide polymorphism (SNP) of MHC class II HLA-DRB5 with AD implies a potential T cell-mediated process [92]. To assess the overall function of the adaptive immunity, two groups analyzed severely immunocompromised transgenic mice expressing human mutant APP and obtained conflicting results. PSAPP:Rag2 ${ }^{-1-}$ mice lacking $B$ and $T$ cells showed reduced $A \beta$ pathology accompanied by highly phagocytic microglia [93], whereas 5xFAD:Rag2 $2^{-/}: \mathrm{Il}_{2} \mathrm{rg}^{-/-}$mice lacking $B, T$ and NK cells displayed exaggerated $A \beta$ plaque deposition and increased neuroinflammation [94]. While the two mouse models do differ in several aspects, the primary reason for the discrepant observations is unclear. Given the memory and behavior impairment in $\operatorname{Rag}^{2 /-}$ mice $[68,95,96]$, how this may confound $\mathrm{A} \beta$-associated functional decline was not addressed.

\section{$B$ cells in adaptive immunity}

Humoral immune response (i.e. antibody production) by $B$ cells to amyloid $\beta$ has been studied for over 20 years.
It was first discovered that immortalized B cells from the peripheral blood of an $\mathrm{AD}$ patient secreted antibodies that specifically recognize $A \beta$ peptide [97]. Circulating anti-A $\beta$ antibody at various levels has since been detected in the blood of human subjects with or without AD [98-101]. The groundbreaking study by Schenk et $\mathrm{al}$, in which $\mathrm{A} \beta$ immunization prevented the development of amyloid plaques, neuritic dystrophy and gliosis in PDAPP mice, demonstrated the therapeutic potential of B cell-mediated immune response [102]. However, human vaccination trial AN1792 based on the same principle had to be halted due to life-threatening encephalitis, which was later attributed largely to the pathogenic autoimmune $\mathrm{T}_{\mathrm{H}} 1$ response stimulated by active immunization (see next section). Subsequent studies in animal models demonstrated the ability of individual $\mathrm{A} \beta$-specific antibody clones to attenuate $\mathrm{AD}$ pathogenesis without the involvement of $\mathrm{T}$ cells, lending support for the clinical trials to passively immunize AD patients with anti-A $\beta$ antibodies. However, such a strategy has yielded mixed outcomes with several trials still ongoing (reviewed by [103-105]; also see section Passive Immunotherapy)).

Besides the humoral response specific to proteins associated with $\mathrm{AD}$ pathology, the peripheral immunoglobulin repertoire is dysregulated in AD. Spontaneously secreted by B cells without exogenous stimulation, natural antibodies are abundant in normal sera, typically poly- or self-reactive, and fulfill important functions of targeting pathogens and removing cellular and molecular waste in the body [106]. The levels of natural IgG recognizing self-antigens was shown to be influenced by age, sex and disease [107]. Significant reduction of the number of autoantibodies was detected in the sera from patients with AD, Parkinson's disease (PD), and multiple sclerosis, a neuroinflammatory condition [107]. The cause and functional significance of such a decrease is unclear. Unexpectedly, a recent time-course global proteomic analysis of $\mathrm{APP}^{\mathrm{NL}-\mathrm{F}}$ mice reported an inverse correlation between $A \beta$ burden in the brain and IgM levels in the blood [108]. Again, the implication of this finding remains to be seen. Nevertheless using a panel of autoantibodies as biomarkers, DeMarshall et al. were able to differentiate mild-moderate $\mathrm{AD}$ patients from age-matched controls, MCI, and other neurological disorders with high confidence [109].

Another insight on the role of immunoglobulin in AD came from the study by Marsh et al. [94]. Increased mouse IgGs were detected in association with microglia in the brains of 5xFAD mice. Lacking specificity for $A \beta$, these proteins were shown to engage with microglia $\mathrm{Fc}$ receptor, induce an activating signaling pathway, and stimulate phagocytosis of $A \beta$, which lead to a decreased plaque load. Although the antigen-specificity of the 
infiltrating IgG was not studied in this study, the protective effect of mouse IgG is reminiscent of the beneficial influence previously reported with intravenous Immunoglobulin (IVIg), a pooled human IgG product [110-112]. Whether any specific subset of the natural IgGs confers enhanced neuroprotection remains to be investigated.

\section{$T$ cells in adaptive immunity}

Inside the post-mortem brains of $\mathrm{AD}$ patients, both $\mathrm{CD}^{+}{ }^{+}$and $\mathrm{CD} 8^{+} \mathrm{T}$ cells were detected, occasionally next to the neuritic plaques or microglia [113-115]. Similarly, increased numbers of $\mathrm{T}$ cells have been found infiltrating the brain parenchyma of multiple transgenic mice expressing mutant human APP [116, 117]. In one study, significant fractions of infiltrating $\mathrm{T}$ cells were found to produce IFN $\gamma$ and IL-17 in APP/PS1 brain [117]. However, Ferretti et al. reported that infiltrating $\mathrm{T}$ cells consistently display an inactivated phenotype with reduced IFN $\gamma$ production and lack of local proliferation and do not co-localize with amyloid plaques in three AD models (ArcA $\beta, A P P / P S 1$ and Tg2576) [116]. In line with this, peripheral $\mathrm{CD}_{4}^{+} \mathrm{T}$ cells were found hyporesponsive to A $\beta$ peptides in $\operatorname{Tg} 2576$ mice, which resulted in a defective $A \beta$-specific antibody response [118]. In humans, an early study reported unresponsiveness to $A \beta 40$ peptide by peripheral lymphocytes from AD patients [119]. However, peripheral $\mathrm{T}$ cells reactive to $\mathrm{A} \beta 42$ peptide, which is more immunogenic than $A \beta 40$, was later found significantly increased in $\mathrm{AD}$ patients and older adults over middle-aged healthy controls [120]. T regulatory cells (Tregs) are a crucial $\mathrm{T}$ cell subset that suppresses effector immune responses and maintains immune tolerance. $\mathrm{AD}$ and Down syndrome patients both display $\mathrm{A} \beta$ plaque accumulation and similarly have increased A $\beta$-specific IL-10-producing Treg cells in their blood [121]. Elevated Treg levels and suppressive activities in the periphery of $\mathrm{AD}$ patients were reported by other groups [122-124], which is affirmed by the increased FoxP3 $^{+}$Tregs in the spleens of 5xFAD mice [125].

Given the distinct and powerful roles played by $\mathrm{T}$ helper subsets in numerous diseases, it would be vital to dissect how different $T_{H}$ cell populations specifically modulate AD. In the APP/PS1 model, adoptive transfer of $A \beta$-specific $\mathrm{T}_{\mathrm{H}} 1$ cells, but not $\mathrm{T}_{\mathrm{H}} 2$ or $\mathrm{T}_{\mathrm{H}} 17$ cells, led to their homing to the brain and worsened $\mathrm{AD}$ pathology along with impaired cognitive function and exaggerated microglia activation [117]. The pathogenic and plaque clearing roles of $\mathrm{T}_{\mathrm{H}} 1$ cells were demonstrated in an earlier study, in which, post-A $\beta$ vaccination, $\mathrm{A} \beta$-specific IFN $\gamma$-producing $\mathrm{T}$ cells infiltrated the brain of J20 mice to clear amyloid plaques but induced meningoencephalitis, mirroring the pathogenic events of the failed human vaccination trial AN1792 [126]. However, direct cerebrospinal injection of $A \beta$-specific $T_{H} 1$ cells led to amyloid plaque clearance and increased neurogenesis in the absence of autoimmunity, implying an added impact of peripheral $\mathrm{T}_{\mathrm{H}} 1$ cells in APP/PS1 model [127]. On the other hand, adoptively transferred $A \beta$-specific $\mathrm{T}_{\mathrm{H}} 2$ cells, while with no evidence of brain filtration, improved working memory of APP/PS1 mice in conjunction with reduced systemic inflammation and vascular amyloidosis [128]. Therefore, $A \beta$-specific $T_{H} 1$ and $T_{H} 2$ effector subsets seemingly alter the $A \beta$ pathology in distinct ways (Table 2).

Substantial yet contradictory impacts of Tregs on AD pathogenesis have been demonstrated by recent studies in several experimental models (Table 3). By way of antibody-mediated depletion, adoptive transfer of purified cells, and low-dose IL-2-induced peripheral expansion, multiple groups independently provided experimental evidence that collectively suggested an overall protective role of Tregs in restoring memory deficits, reducing plaque load and decreasing microglia activation as well as inflammation in several APP transgenic models [129-132]. These results are consistent with the impaired learning and memory in IL- $2^{-/}$mice, which lack functional Tregs [133]. Whether Tregs convey neuroprotection in an antigen-specific manner is not clear at this time.

On the other hand, two consecutive reports from Michal Schwartz's group strongly argued for detrimental effects of Tregs in AD pathogenesis $[125,134]$. They first demonstrated that 5xFAD mice

Table 2 Aß-specific T cell subsets regulate AD pathogenesis in experimental models

\begin{tabular}{|c|c|c|c|c|c|}
\hline Subset & Location & AD Model & Specificity & Effects on pathogenesis & $\overline{\text { Reference }}$ \\
\hline$\overline{T_{H} 1}$ & Parenchyma & APP/PS1 & $A \beta$ & Adoptively transferred cells increased microglia activation and $A \beta$ deposition & [117] \\
\hline$T_{H} 1$ & Parenchyma & $\begin{array}{l}J 20 \text { with } A \beta \\
\text { peptide } \\
\text { vaccination }\end{array}$ & $A \beta$ & $\begin{array}{l}\text { Migrated to } A \beta \text { plaques with increased clearance, while inducing transient } \\
\text { meningoencephalitis }\end{array}$ & [126] \\
\hline $\mathrm{T}_{\mathrm{H}} 1$ & Parenchyma & APP/PS1 & $A \beta$ & $\begin{array}{l}\text { Cells injected to cerebrospinal ventricle migrated to } A \beta \text { plaques, increased } \\
A \beta \text { clearance and promote neurogenesis }\end{array}$ & [127] \\
\hline $\mathrm{T}_{\mathrm{H}} 2$ & $\begin{array}{l}\text { Outside the } \\
\text { brain }\end{array}$ & APP/PS1 & $A \beta$ & $\begin{array}{l}\text { Adoptively transferred cells improved working memory, decreased microgliosis } \\
\text { and reduced plasma cytokines. No effect on plaque load inside the parenchyma } \\
\text { but reduced vascular amyloidosis }\end{array}$ & [128] \\
\hline
\end{tabular}


Table 3. Treg cells regulate AD pathogenesis in experimental models

\begin{tabular}{|c|c|c|c|c|c|}
\hline Subset & Location & AD model & Specificity & Effects on pathogenesis & Reference \\
\hline $\mathrm{T}_{\text {reg }}$ & Systemic & APP/PS1 & bulk & $\begin{array}{l}\text { Transient depletion of Treg accelerated cognitive decline; increased Treg } \\
\text { with low-dose IL-2 treatment restored cognitive functions }\end{array}$ & [129] \\
\hline$T_{\text {reg }}$ & Systemic & $3 \times \operatorname{Tg}$ & bulk & $\begin{array}{l}\text { Adoptively transferred cells improved cognitive functions and reduced A } \beta \\
\text { deposition; long-term Treg depletion resulted in exacerbated spatial learning } \\
\text { deficits, A } \beta \text { plaque load and microgliosis }\end{array}$ & [130] \\
\hline$T_{\text {reg }}$ & $\begin{array}{l}\text { Systemic and } \\
\text { Parenchyma }\end{array}$ & App/PS1 $\Delta$ E9 & bulk & $\begin{array}{l}\text { AAV- } I L-2 \text { expression within the brain induced Treg expansion and astrocyte } \\
\text { activation, reduced A } \beta \text { plaque and improved synaptic plasticity and spine density }\end{array}$ & [131] \\
\hline $\mathrm{T}_{\text {reg }}$ & Systemic & AßPPswe/PS1 $\Delta$ E9 & bulk & $\begin{array}{l}\text { Adoptively transferred cells improved cognitive function, while reducing } A \beta \\
\text { deposition, microgliosis and systematic inflammation }\end{array}$ & [132] \\
\hline $\mathrm{T}_{\text {reg }}$ & Systemic & 5xFAD APP/PS1 & bulk & $\begin{array}{l}\text { Transient depletion or pharmacological inhibition of Treg lead to } A \beta \text { plaque } \\
\text { clearance, reduced neuroinflammation and reversal of cognitive decline. It affected } \\
C P \text { with increased recruitment of peripheral monocytes and Tregs to } A \beta \text { plaque }\end{array}$ & [125] \\
\hline $\mathrm{T}_{\text {reg }}$ & Systemic & $5 \times F A D$ & bulk & $\begin{array}{l}\text { Anti-PD1 treatment stimulated IFN }{ }^{-} \text {-dependent systematic immune response, } \\
\text { which resulted in the recruitment of peripheral monocytes and Tregs to A } \\
\text { plaque, clearance of plaque, and improvement of cognitive performance. } \\
\text { Repeated treatments maintained a long-lasting beneficial effects }\end{array}$ & [134] \\
\hline $\mathrm{T}_{\text {reg }}$ & & $\begin{array}{l}\text { ThyAPP/PS1 } 1_{\mathrm{m} 146 L} \\
\text { ThyAPP/PS1 A246E } \\
\text { PD-APP }\end{array}$ & bulk & $\begin{array}{l}\text { Anti-PD1 treatments had no effect on amyloid pathology nor induced } \\
\text { infiltration of peripheral monocyte into the brain }\end{array}$ & [135] \\
\hline
\end{tabular}

have reduced expression in choroid plexus of molecules critical for transepithelial migration, which correlated with the loss of IFN $\gamma$ signaling, a condition similar to brain aging [125]. This led to a hypothesis that a dysregulated $\mathrm{CP}$ exacerbates $\mathrm{AD}$ pathogenesis by blocking protective immune cell infiltration. Since Tregs are the primary suppressor of IFN $\gamma$-producing $\mathrm{T}_{\mathrm{H}} 1$ cells, depleting or disabling Treg function was shown to restore IFNy signaling in $\mathrm{CP}$, increase the number of peripheral immune cells in the parenchyma, clear amyloid plaques, and rescue memory and behavior defects in 5xFAD mice $[125,134]$. In more detail, Baruch et al. perturbed the Treg population by various experimental schemes, which included selective depletion in 5xFAD:FoxP3-DTR mice with diphtheria toxin, chemical treatments to boost or diminish the functionality of Tregs or stimulate their induction, and administrating antibody against PD1 to break Treg suppression in 5xFAD and/or APP/PS1 models (Table 3).

At this time, it is unclear whether these directly opposing results reported on Tregs are affected by the genetic background of the AD models or other factors. Nevertheless, a $\mathrm{T}$ cell-based intervention with anti-PD1 antibody, which is largely analogous to the cancer checkpoint immunotherapy, was proposed as a translatable approach of $\mathrm{AD}$ therapeutics based on the findings by Baruch et al. [135]. However most recently, a joint study by three pharmaceutical companies questioned the effectiveness of systemic PD-1 blockade in modifying amyloid burden in several AD mouse models, where the authors also failed to detect monocyte infiltration into the brain ([136]; Table 3).
Hence, the mechanism of how Tregs modulate $A \beta$ pathology remains to be fully elucidated and the pre-clinical support for PD-1 blockade approach in $\mathrm{AD}$ patients is weak at this time.

\section{Peripheral immune responses modify AD pathogenesis Pathogens}

The brain can readily respond to inflammatory signals originated from the periphery. For example, peripheral administration of microbial mimetics, such as LPS and polyI:C, that induce strong systemic inflammatory response, exacerbates neurodegeneration [137, 138]. Microglia are shown to be highly receptive to these treatments and the resulting enhanced neuroinflammation compels the disease pathogenesis [139]. Living in a bustling world, humans are exposed to exogenous infectious agents, cohabit with a complex microbiome, and are afflicted increasingly by chronic ailments as we age. Immune system is the frontline protection against microbial infections. When the infectious agents are not well controlled, HIV patients develop dementia that is highly analogous to AD, West Nile Virus infection leads to long term cognitive impairment, and periodontitis exacerbates the cognitive decline in $\mathrm{AD}$ patients, etc. [140-142].

\section{Microbiota}

Mammals host trillions of microbes that reside in the barrier tissues such as gut, skin, and lung. Research in recent years have revealed a dynamic interaction between the microbiome and the immune system and the pathogenic outcomes of dysbiosis [143, 144]. Microbes in the gut profoundly affect the development of 
microglia [145] and effectively prime microglia in the brain via secreted short-chain fatty acids [146], highlighting an eminent gut-brain axis [147]. Several studies have suggested that gut microbiota plays a vital role in the pathogenesis of PD via modulating neuroinflammation $[148,149]$. To understand its potential relevance to AD, two groups surveyed the gut microbe taxa in elderly individuals. AD patients have reduced microbial diversity and harbor a distinct bacteria genera, which is correlated with changes in CSF biomarkers [150]. A similar association was made between inflammatory bacteria and proinflammatory circulating cytokines in patients with cognitive impairment [151]. Consistent with this, a shift in the gut microbiota was detected in APP/PS1 mice compared with non-transgenic controls. Depletion of microbiota by antibiotic treatments or germ-free host re-derivation resulted in reduced $A \beta$ plaque load in conjunction with altered microglia morphology $[152,153]$. Intriguingly, transient perturbation of microbial diversity in APP/PS1 mice shortly after birth can result in long-lasting alteration of brain A $\beta$ pathology [154]. Although microbiota can modulate CNS profiles in mice [155], whether and how gut microbiota affect cognition and memory in $\mathrm{AD}$ models has yet to be fully revealed. This area of research is being actively pursued and will surely help illuminate how such key environmental factor modulate $\mathrm{AD}$ risk and progression.

\section{Chronic inflammation}

A recent prospective survey of 1,633 participants revealed a positive association between midlife peripheral inflammation and shrinkage of brain volume in late-life [156]. Not unexpectedly, a genetic epidemiology study identified SNPs that are shared between LOAD and common chronic inflammatory diseases, such as psoriasis, type 1 diabetes and Crohn disease [92]. Chronic conditions with inflammatory traits, such as vascular diseases and diabetes, are well-known comorbidities of AD. Aging is also associated with higher incidents of autoinflammatory diseases, such as rheumatoid arthritis (RA) and psoriasis, two diseases also co-morbid with $\mathrm{AD}[157,158]$. RA patients receiving anti-inflammatory treatments have overall reduced risk of developing $\mathrm{AD}$, and peripheral neutralization of TNF- $\alpha$, a key cytokine driving RA pathogenesis, was shown effective in AD animal models [159]. Therefore, diverse systemic inflammatory responses play a crucial role in modulating $\mathrm{AD}$ pathogenesis.

\section{Therapeutic applications in AD by harnessing the immune system}

Deemed the greatest global challenge for health and social care in the $21^{\text {st }}$ century, dementia affected an estimated 47 million people globally in 2015, a number which may increase to 131 million by 2050 as the world's population ages. The task to develop effective treatments for $\mathrm{AD}$ is exceedingly daunting, due to the multifaceted nature of the disease, lack of sensitive and definitive biomarkers, incomplete understanding of the pathogenic and regulatory pathways, dearth of disease stage-specific molecular targets, and technical difficulties for effective CNS drug delivery. Nevertheless, a range of strategies harnessing our knowledge of immune responses and aging/AD pathogenesis are being actively pursued.

\section{Passive immunotherapy}

Despite the strong implication of $A \beta$ peptide in $A D$, strategies targeting monomeric $A \beta$ failed in late stage AD populations $[104,160]$. Along the protein misfolding pathway, soluble oligomeric assemblies are recognized as the primary pathogenic species of misfolded proteins $[161,162]$. Although antibodies against different forms of aggregated $A \beta$ are detected in the peripheral blood of healthy individuals, the levels of these antibodies decrease with normal aging and decline further with progression from mild to severe AD [163, 164]. Inoculation of antibodies recognizing aggregated $A \beta$ effectively modified amyloid plaque pathology and rescued cognitive decline in AD animal models [165-167]. Given the protective humoral response in the host, a "reverse translational medicine" approach was devised. A fully humanized IgG1 mAb reactive to aggregated but not monomeric $A \beta$, aducanumab, was obtained from a screen of healthy advanced-age donors with normal cognition who presumably harbor naturally developed protective mAbs against $A \beta$. Preliminary results from a double-blind, placebo-controlled phase $1 \mathrm{~b}$ trial with aducanumab showed reduced brain $\mathrm{A} \beta$ plaques in a doseand time-dependent manner and a trend of slowing clinical decline in AD patients [167]. Two large-scale phase 3 trials with aducanumab are ongoing and will be completed in 2022. In addition to $A \beta$, antibodies specific to tau protein are also being actively evaluated for their clinical potentials [160].

One significant impediment for the success of passive immunotherapy for $\mathrm{AD}$ is the insufficient entry of antibodies into the CNS. It was estimated that only approximately $0.1 \%$ of peripherally-administered antibody can enter the brain in the presence of an intact blood brain barrier (BBB), a network of vascular endothelial cells, pericytes and astrocytes, which significantly blunted the drug availability inside the brain $[168,169]$. Different strategies are being devised to improve CNS delivery of therapeutic antibodies. A bispecific antibody design with one arm recognizing transferrin receptor, a surface molecule highly expressed by BBB endothelial cells, greatly enhanced transcytosis of the antibody across the $\mathrm{BBB}$ and 
increased the antibody levels inside the brain $[170,171]$. On the other hand, transient opening of the BBB can be achieved by focused ultrasound treatment, which was shown to result in the reduction of amyloid burden in $\mathrm{AD}$ models and enhanced the protective effect of a tau-specific antibody in vivo recently [172-175].

\section{Targeting immune molecules}

Consistent with the notion of a pathogenic influence of inflammation, early epidemiological studies suggested that long term use of anti-inflammatory drugs was associated with reduced risk of developing $\operatorname{AD}[176,177]$. This led to multiple clinical trials designed to suppress general inflammation, which included using nonsteroidal anti-inflammatory drugs, statins, low dose-prednisone, and NF- $\mathrm{kB}$ blocker, etc.; however, no clinical benefit has been demonstrated in AD patients (reviewed in $[178,179]$ ). Intravenous immunoglobulins have been used clinically for treating various autoimmune and infectious diseases and exhibited protective effects in AD animal models, as discussed earlier [110, 111]. Yet, clinical trials with IVIg failed to show positive effect [180-182].

Given the complex role played by immune cells and responses inside and outside the brain, a deeper understanding of the molecular mechanisms is a prerequisite for translational success. Therapies targeting specific immune molecules that are crucial in AD pathogenesis or protection presumably offer improvement over non-specific interventions. TNF- $\alpha$ is a proinflammatory cytokine highly implicated in many peripheral inflammatory diseases as well as AD. Peripheral TNF- $\alpha$ neutralization was effective in reducing $A \beta$ plaques and neuronal dysfunction in an AD model [159]. A small, double-blind, placebo-controlled phase 2 trial with Etanercept, a decoy receptor for TNF- $\alpha$, reported a tolerated response [183]. Yet, future trial with large patient cohort is necessary to establish the effectiveness of this strategy. On the other hand, administration of the cytokine Granulocyte-Macrophage Colony-Stimulating Factor (GM-CSF) was shown effective in improving memory in aged mice, reducing brain amyloidosis and reversing the cognitive impairment in $\mathrm{AD}$ mice, and associated with improved cognition in cancer patients [55, 184, 185]. A small number of AD patients treated with Leukine ${ }^{\circ}$, recombinant human GM-CSF, reported rapid improvement of cognitive functions in a double-blind, placebo-controlled phase 2 trial [186].

\section{Anti-aging strategies}

Besides disease-specific targeting, slowing down the clock of age-related systemic decline should be beneficial for a wide spectrum of diseases, including AD. Although most studies were carried out in rodents, the exciting findings on the power of young blood and molecules with capacity to rejuvenate the old offer a novel prospect of therapeutics [46]. An ongoing phase I Plasma for Alzheimer's Symptom Amelioration (PLASMA) trial examines the safety, tolerability and feasibility of infused blood plasma from young donors to patients with mild to moderate Alzheimer's disease [187]. Alternatively, via selective destruction of senescent cells, senolytics have emerged recently as a novel class of anti-aging agents in animal studies. In the coming years, therapeutic potential to target senescence in humans will surely be explored (reviewed in [44]).

\section{Conclusions}

We have summarized the knowledge gained in recent years on the changes of the periphery in aging and Alzheimer's disease and the emerging significance of the peripheral immune system and their responses in modulating $\mathrm{AD}$ pathogenesis. It is thus apparent that the prevailing neuro-immune connection is not limited to localized neuroinflammation inside the brain. Here we emphasize the importance of diverse signals from the periphery to modify the course of $\mathrm{AD}$ pathogenesis (Fig. 2). The systemic influences comprise a multitude of age-dependent organismal changes, protective and pathogenic immune cell surveillance, and ongoing immune responses to environmental factors and self-derived molecules. These elements operate jointly and dynamically with the ongoing brain-intrinsic aging and degenerative processes. We believe such

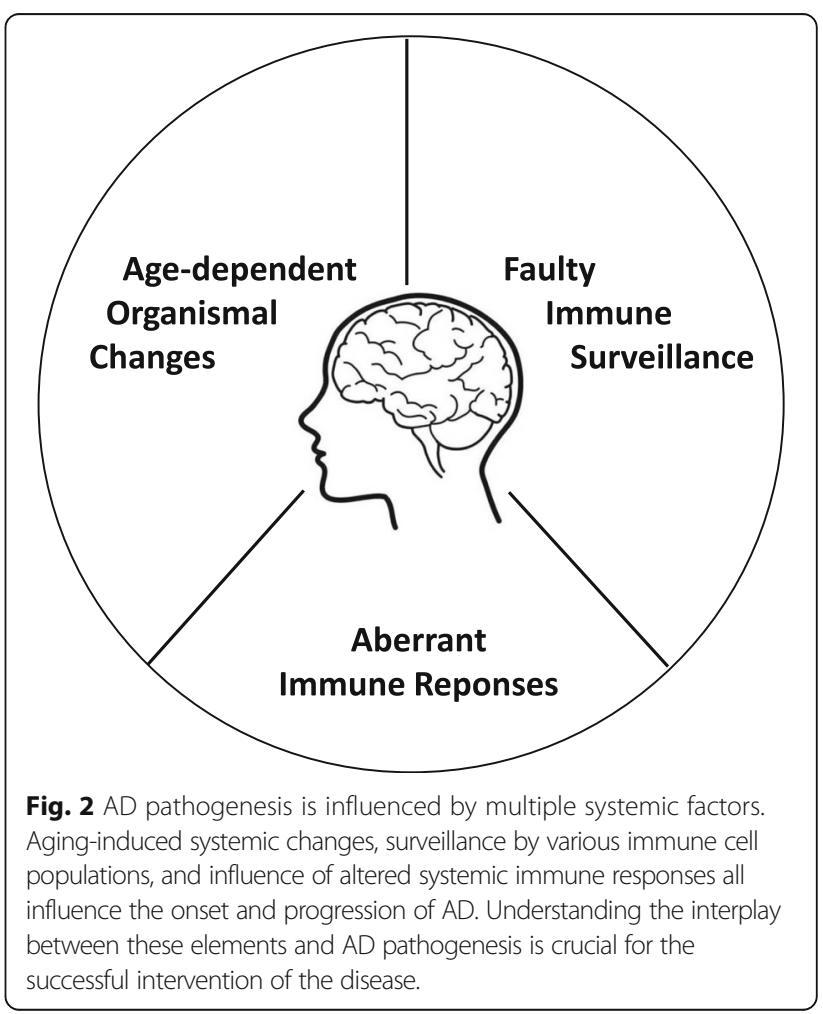


understanding helps comprehend the vast amount of existing literature and expand our perspectives in $\mathrm{AD}$ research.

Despite the latest immense interest in understanding the role of immune system modulation in $\mathrm{AD}$, some major knowledge gaps remain. Below we identify six key areas that the field should address in the future:

\section{Contribution of aging to AD}

Given the importance of aging in LOAD, it is not surprising that $\mathrm{AD}$ pathology in vivo is modulated highly by immune responses in an age- and disease-state dependent manner [188, 189]. This poses a significant problem since the development of AD has been mostly studied in adult, but not necessarily advanced-age, animals so far. With the advent of increasingly refined knock-in and transgenic AD animal models [190, 191], analysis of properly aged hosts will offer opportunity to evaluate the physiologically relevant contributing factors in $\mathrm{AD}$ pathogenesis and to test the efficacy of targeted regimen for translational potential. In the coming years, it would also be critical to establish and dissect how senescence within and outside CNS partakes in $\mathrm{AD}$ pathogenesis.

\section{A systematic understanding of LOAD}

Genetic studies of LOAD have identified numerous immune-related risk factors [4-6]. The involvement of implicated genes and related pathways in $\mathrm{AD}$ has been investigated in genetically engineered mouse models in recent years [84, 189, 192-195]. It is important to note that these genes and pathways are expressed at elevated levels both inside the brain and in the periphery in aging and/or AD, such as TREM2, inflammasome, and complement cascade as discussed earlier. Since the in vivo studies focused primarily on events within CNS, the contribution of simultaneously altered peripheral immune compartment is largely ignored. Recently identified as genetic risk factors in the Chinese population, risk variants of both $\mathrm{GCH} 1$ and $\mathrm{KCNJ} 15$ have altered expression in the peripheral immune cells of AD subjects, suggesting apparent functional effects through the immune system [196]. Examination of the peripheral leukocytes and their alterations together with the cells inside the brain should provide further insights on how the immune system comprehensively influences $\mathrm{AD}$ pathogenesis. With the same goal, it would also be necessary to examine the effects of lineage-specific gene knockouts to thoroughly dissect the immune compartments critical for the assigned gene function.

\section{Adaptive immune system in AD pathogenesis}

Despite genetic evidence implicating adaptive immunity in $\mathrm{AD}$ [91, 92], it remains ill-defined how adaptive immune cells with limited presence inside the parenchyma exert their effects on AD pathologies and cognitive functions. Nevertheless, $T$ cells have been shown to participate in other neurodegenerative diseases, such as PD and amyotrophic lateral sclerosis [197, 198]. As reviewed earlier, many inconsistent results have been reported on the impacts of T cell subsets on CNS pathogenesis in $\mathrm{A} \beta$-based experimental models. Thus, it is critical in the future to reconcile the main findings and differentiate the neuro-protective molecules, cells, and responses from the pathogenic ones, while elucidating the context-dependent functions influenced by specific host factors. Noticeably missing at this time is the examination of tau-specific $\mathrm{T}$ cells and the possible involvement of Treg cells in tau pathology, a major gap in understanding the participation of the adaptive immune arm in AD pathogenesis. Despite the technical challenge to study rare cells, new technologies such as high-dimensional single-cell analysis should significantly improve the quantification and classification of diverse immune cell populations in the $\mathrm{AD}$ brain. Whether $\mathrm{T}$ and B cells, self-reactive or bystanders, afford protective immune surveillance or pathogenic immune attack requires thorough delineation.

\section{Peripheral immune responses in modulating AD}

Despite strong clinical implications, how peripheral immune responses influence $\mathrm{AD}$ progression remains enigmatic. Though useful and informative, current animal models of $\mathrm{AD}$, however, have severe limitations in their capacity to facilitate immunological inquiries. The animals are usually analyzed after life-long housing in the absence of natural microbial pathogens, which may result in reduced host fitness and poor disease resistance [143]. Given the importance of gut microbiota, alternative experimental modeling that incorporates the elements of peripheral conditioning is imperative for dissecting the immune responses in $\mathrm{AD}$. One fundamental question is whether peripheral responses alone are sufficient to initiate the process of neuroinflammation and eventually drive neuropathology under any circumstances. Equally important is to understand whether peripheral events can imprint CNS with long-lasting alterations, a notion highlighted by the detected microglia memory formed upon peripheral LPS administrations [199]. On the other hand, high-dimensional and functional peripheral immune profiling of $A D$ patients may reveal much needed insights into ongoing peripheral responses, which may help stratify the patients for targeted therapeutic interventions.

\section{Neurovascular interface in AD}

The brain is dynamically circulated not only by blood vessels, but also via a perivascular network and 
meningeal lymphatic vessels [200, 201]. In AD, it yet has to be revealed how peripheral immune cell populations traverse through these neurovascular networks to enter, remain in, and exit the brain, and more importantly, the functional outcome of such events. It is equally unclear how specific components of the neurovascular barrier is differentially regulated by the inflammatory milieu of AD. Understanding the selectivity of gateway trafficking for leukocytes and the associated regulatory mechanism is critical not only for dissecting the crosstalk between the periphery and CNS, but also for devising therapeutic strategies to modify such interactions.

\section{Neuro-immune feedback mechanism in AD}

The immune system and the nervous system share several key features: both regulate physiological homeostasis and protect the host from threats; both are composed of heterogeneous cell populations with extensive functional specialization; and both use synapses and soluble factors for cell-to-cell communication and memory formation [202, 203]. With expression of receptors for cytokines and neural transmitters, immune cells and nerve cells crosstalk and cooperate to maintain the homeostasis of the host. Although we have focused on the effects of peripheral inflammation on CNS, it is known that CNS can exert control of peripheral immune responses through spinal sympathetic and brain stem vagus nerve efferent signaling [204, 205]. For example, the vagus-nerve-based circuit inhibits TNF- $\alpha$ production in the spleen via the splenic nerve, acetylcholine-synthesizing $\mathrm{T}$ cells, and response by macrophage to acetylcholine [206]. Among the brain regions that integrate and regulate neuro-immune reflex, both thalamus and hypothalamus harbor pathological changes in AD patients $[207,208]$. Therefore, it would be interesting to investigate whether the CNS regulatory circuit is compromised in $\mathrm{AD}$, which may result in dysregulated peripheral immune responses and consequently a feedforward loop for systemic inflammation.

Overall, a new era of discovery compels us to fully grasp the many molecular and cellular players that partake the neuro-immune communications in $\mathrm{AD}$ and other neurodegenerative diseases under aging conditions. Better deciphering the influence of the immune system on the brain will surely provide further insights and guidance for the development of next-generation therapeutics.

\footnotetext{
Abbreviations

AD: Alzheimer's disease; APP: Amyloid precursor protein; A $\beta$ : Amyloid $\beta$ : BBB: Blood brain barrier; CNS: Central nervous system; CSF: Cerebrospinal fluid; GDF-11: Growth and differentiation factor 11; IFN-I: Type I interferon; IVlg: Intravenous Immunoglobulin; LOAD: Late-onset Alzheimer's disease; SASP: Senescence-associated secretory phenotype; SNP: Single-nucleotide polymorphism; TCR: T cell receptor; Tregs: T regulatory cells; TREM2: Triggering Receptor Expressed on Myeloid cells 2
}

\section{Acknowledgements}

The authors would like to thank Ethan Roy for assistance in editing the manuscript.

\section{Funding}

This work was supported by NIH grants AG057587 (WC), AG020670,

AG032051 and AG054111 (HZ)

\section{Authors' contributions}

WC proposed the topic of the paper, reviewed the literature, drafted and revised the manuscript, and constructed the figures. $\mathrm{HZ}$ critically revised the manuscript. All authors read and approved the final manuscript.

\section{Ethics approval and consent to participate}

Not applicable

\section{Consent for publication}

Not applicable

\section{Competing interests}

The authors declare that they have no competing interests.

\section{Publisher's Note}

Springer Nature remains neutral with regard to jurisdictional claims in published maps and institutional affiliations.

Received: 31 August 2018 Accepted: 21 September 2018

Published online: 03 October 2018

\section{References}

1. Hardy J, Selkoe DJ. The amyloid hypothesis of Alzheimer's disease: progress and problems on the road to therapeutics. Science. 2002;297.

2. Selkoe DJ, Hardy J. The amyloid hypothesis of Alzheimer's disease at 25 years. EMBO Molecular Medicine. 2016.

3. Walsh DM, Selkoe DJ. A critical appraisal of the pathogenic protein spread hypothesis of neurodegeneration. Nat Rev Neurosci. 2016;17:251-60.

4. Lambert JC, Ibrahim-Verbaas CA, Harold D, Naj AC, Sims R, et al. Metaanalysis of 74,046 individuals identifies 11 new susceptibility loci for Alzheimer's disease. Nat Genet. 2013:45:1452-8.

5. Sims R, van der Lee SJ, Naj AC, Bellenguez C, Badarinarayan N, et al. Rare coding variants in PLCG2, ABI3, and TREM2 implicate microglial-mediated innate immunity in Alzheimer's disease. Nat Genet. 2017; advance online publication.

6. Efthymiou AG, Goate AM. Late onset Alzheimer's disease genetics implicates microglial pathways in disease risk. Mol Neurodegener. 2017;12:43.

7. Heneka MT, Carson MJ, El Khoury J, Landreth GE, Brosseron F, Feinstein DL, Jacobs AH, Wyss-Coray T, Vitorica J, Ransohoff RM, Herrup K, Frautschy SA, Finsen B, Brown GC, Verkhratsky A, Yamanaka K, Koistinaho J, Latz E, Halle A, Petzold GC, Town T, Morgan D, Shinohara ML, Perry VH, Holmes C, Bazan NG, Brooks DJ, Hunot S, Joseph B, Deigendesch N, Garaschuk O, Boddeke E, Dinarello CA, Breitner JC, Cole GM, Golenbock DT, Kummer MP. Neuroinflammation in Alzheimer's disease. Lancet Neurol. 2015;14:388-405.

8. Ransohoff RM. How neuroinflammation contributes to neurodegeneration. Science. 2016;353:777-83.

9. Heppner FL, Ransohoff RM, Becher B. Immune attack: the role of inflammation in Alzheimer disease. Nat Rev Neurosci. 2015;16:358-72.

10. Hickman SE, Kingery ND, Ohsumi TK, Borowsky ML, Wang LC, Means TK, El Khoury J. The microglial sensome revealed by direct RNA sequencing. Nat Neurosci. 2013:16:1896-905.

11. Galatro TF, Holtman IR, Lerario AM, Vainchtein ID, Brouwer N, Sola PR, Veras MM, Pereira TF, Leite REP, Moller T, Wes PD, Sogayar MC, Laman JD, den Dunnen W, Pasqualucci CA, Oba-Shinjo SM, Boddeke EWGM, Marie SKN, Eggen BJL. Transcriptomic analysis of purified human cortical microglia reveals age-associated changes. Nat Neurosci. 2017; advance online publication.

12. Soreq L, Consortium UKBE, North American Brain Expression C, Rose J, Soreq E, Hardy J, Trabzuni D, Cookson MR, Smith C, Ryten M, Patani R, Ule J. Major Shifts in Glial Regional Identity Are a Transcriptional Hallmark of Human Brain Aging. Cell Rep. 2017;18:557-70.

13. Salter MW, Stevens B. Microglia emerge as central players in brain disease. Nat Med. 2017;23:1018-27. 
14. Sarlus H, Heneka MT. Microglia in Alzheimer's disease. J Clin Invest. 2017; 127:3240-9.

15. Biber K, Moller T, Boddeke E, Prinz M. Central nervous system myeloid cells as drug targets: current status and translational challenges. Nat Rev Drug Discov. 2016;15:110-24.

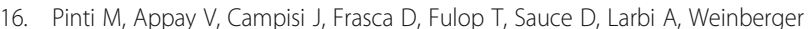
$B$, Cossarizza A. Aging of the immune system: Focus on inflammation and vaccination. Eur J Immunol. 2016;46:2286-301.

17. Goldberg EL, Dixit VD. Drivers of age-related inflammation and strategies for healthspan extension. Immunol Rev. 2015;265:63-74.

18. Franceschi C, Campisi J. Chronic inflammation (inflammaging) and its potential contribution to age-associated diseases. J Gerontol A Biol Sci Med Sci. 2014;69(Suppl 1):S4-9.

19. Netea MG, van de Veerdonk FL, van der Meer JWM, Dinarello CA, Joosten LAB. Inflammasome-Independent Regulation of IL-1-Family Cytokines. Annual Review of Immunology. 2015;33:49-77.

20. Latz E, Xiao TS, Stutz A. Activation and regulation of the inflammasomes. Nat Rev Immunol. 2013;13:397-411.

21. Furman D, Chang J, Lartigue L, Bolen CR, Haddad F, Gaudilliere B, Ganio EA, Fragiadakis GK, Spitzer MH, Douchet I, Daburon S, Moreau J-F, Nolan GP, Blanco P, Dechanet-Merville J, Dekker CL, Jojic V, Kuo CJ, Davis MM, Faustin B. Expression of specific inflammasome gene modules stratifies older individuals into two extreme clinical and immunological states. Nat Med. 2017;23:174-84

22. Youm YH, Grant RW, McCabe LR, Albarado DC, Nquyen KY, Ravussin A Pistell P, Newman S, Carter R, Laque A, Munzberg H, Rosen CJ, Ingram DK, Salbaum JM, Dixit VD. Canonical Nlrp3 inflammasome links systemic low-grade inflammation to functional decline in aging. Cell Metab. 2013;18:519-32.

23. Newman AB, Sanders JL, Kizer JR, Boudreau RM, Odden MC, Zeki Al Hazzouri A, Arnold AM. Trajectories of function and biomarkers with age: the CHS All Stars Study. Int J Epidemiol. 2016:45:1135-45.

24. Varadhan R, Yao W, Matteini A, Beamer BA, Xue QL, Yang H, Manwani B, Reiner A, Jenny N, Parekh N, Fallin MD, Newman A, Bandeen-Roche K, Tracy $R$, Ferrucci $L$, Walston J. Simple biologically informed inflammatory index of two serum cytokines predicts 10 year all-cause mortality in older adults. J Gerontol A Biol Sci Med Sci. 2014;69:165-73.

25. Martinez-Jimenez CP, Eling N, Chen H-C, Vallejos CA, Kolodziejczyk AA Connor F, Stojic L, Rayner TF, Stubbington MJT, Teichmann SA, de la Roche M, Marioni JC, Odom DT. Aging increases cell-to-cell transcriptional variability upon immune stimulation. Science. 2017;355:1433-6.

26. Bahar R, Hartmann CH, Rodriguez KA, Denny AD, Busuttil RA, Dolle ME, Calder RB, Chisholm GB, Pollock BH, Klein CA, Vijg J. Increased cell-to-cell variation in gene expression in ageing mouse heart. Nature. 2006;441:1011-4.

27. Enge M, Arda HE, Mignardi M, Beausang J, Bottino R, Kim SK, Quake SR. Single-Cell Analysis of Human Pancreas Reveals Transcriptional Signatures of Aging and Somatic Mutation Patterns. Cell. 2017;171:321-30.e14.

28. Cheung P, Vallania F, Warsinske HC, Donato M, Schaffert S, Chang SE, Dvorak M, Dekker CL, Davis MM, Utz PJ, Khatri P, Kuo AJ. Single-Cell Chromatin Modification Profiling Reveals Increased Epigenetic Variations with Aging. Cell 173. 2018;e14:1385-97.

29. Nikolich-Žugich J. The twilight of immunity: emerging concepts in aging of the immune system. Nature Immunology. 2018;19:10-9.

30. Ucar D, Marquez EJ, Chung CH, Marches R, Rossi RJ, Uyar A, Wu TC, George J, Stitzel ML, Palucka AK, Kuchel GA, Banchereau J. The chromatin accessibility signature of human immune aging stems from CD8(+) T cells. J Exp Med. 2017;214:3123-44.

31. Rudd BD, Venturi V, Li G, Samadder P, Ertelt JM, Way SS, Davenport MP, Nikolich-Zugich J. Nonrandom attrition of the naive CD8+ T-cell pool with aging governed by T-cell receptor:pMHC interactions. Proc Natl Acad Sci U S A. 2011;108:13694-9.

32. Pulko V, Davies JS, Martinez C, Lanteri MC, Busch MP, Diamond MS, Knox K, Bush EC, Sims PA, Sinari S, Billheimer D, Haddad EK, Murray KO, Wertheimer AM, Nikolich-Zugich J. Human memory T cells with a naive phenotype accumulate with aging and respond to persistent viruses. Nat Immunol. 2016:17:966-75

33. Chiu BC, Martin BE, Stolberg VR, Chensue SW. Central memory CD8 T cells in aged mice are virtual memory cells. J Immunol. 2013;191:5793-6.

34. Moskowitz DM, Zhang DW, Hu B, Le Saux S, Yanes RE, Ye Z, Buenrostro JD, Weyand CM, Greenleaf WJ, Goronzy JJ. Epigenomics of human CD8 T cell differentiation and aging. Sci Immunol. 2017;2:eaag0192.
35. Naradikian MS, Hao Y, Cancro MP. Age-associated B cells: key mediators of both protective and autoreactive humoral responses. Immunol Rev. 2016; 269:118-29.

36. Riley RL, Khomtchouk K, Blomberg BB. Age-associated B cells (ABC) inhibit B lymphopoiesis and alter antibody repertoires in old age. Cell Immunol. 2017:321:61-7.

37. Geiger H, de Haan G, Florian MC. The ageing haematopoietic stem cell compartment. Nat Rev Immunol. 2013;13:376-89.

38. He S, Sharpless NE. Senescence in Health and Disease. Cell. 2017;169:1000-11.

39. Ito Y, Hoare M, Narita M. Spatial and Temporal Control of Senescence. Trends Cell Biol. 2017.

40. Munoz-Espin D, Serrano M. Cellular senescence: from physiology to pathology. Nat Rev Mol Cell Biol. 2014;15:482-96.

41. Coppé J-P, Patil CK, Rodier F, Sun Y, Muñoz DP, Goldstein J, Nelson PS, Desprez P-Y, Campisi J. Senescence-Associated Secretory Phenotypes Reveal Cell-Nonautonomous Functions of Oncogenic RAS and the p53 Tumor Suppressor. PLoS Biol. 2008:6:e301.

42. Martinez-Zamudio RI, Robinson L, Roux PF, Bischof O. SnapShot: Cellular Senescence Pathways. Cell. 2017:170, 816-816.e1.

43. Campisi J. Aging, cellular senescence, and cancer. Annu Rev Physiol. 2013; 75:685-705.

44. Childs BG, Gluscevic M, Baker DJ, Laberge RM, Marquess D, Dananberg J, van Deursen JM. Senescent cells: an emerging target for diseases of ageing. Nat Rev Drug Discov. 2017;16:718-35.

45. Salminen A, Ojala J, Kaarniranta K, Haapasalo A, Hiltunen M, Soininen H. Astrocytes in the aging brain express characteristics of senescenceassociated secretory phenotype. Eur J Neurosci. 2011;34:3-11.

46. Wyss-Coray T. Ageing, neurodegeneration and brain rejuvenation. Nature. 2016:539:180-6.

47. Villeda SA, Luo J, Mosher Kl, Zou B, Britschgi M, Bieri G, Stan TM, Fainberg N, Ding Z, Eggel A, Lucin KM, Czirr E, Park J-S, Couillard-Despres S, Aigner L, Li G, Peskind ER, Kaye JA, Quinn JF, Galasko DR, Xie XS, Rando TA, Wyss-Coray $T$. The ageing systemic milieu negatively regulates neurogenesis and cognitive function. Nature. 2011:477:90-4.

48. Smith LK, He Y, Park JS, Bieri G, Snethlage CE, Lin K, Gontier G, Wabl R, Plambeck KE, Udeochu J, Wheatley EG, Bouchard J, Eggel A, Narasimha R, Grant JL, Luo J, Wyss-Coray T, Villeda SA. beta2-microglobulin is a systemic pro-aging factor that impairs cognitive function and neurogenesis. Nat Med. 2015;21:932-7.

49. Sinha M, Jang YC, Oh J, Khong D, Wu EY, Manohar R, Miller C, Regalado SG, Loffredo FS, Pancoast JR, Hirshman MF, Lebowitz J, Shadrach JL, Cerletti M, Kim M-J, Serwold T, Goodyear LJ, Rosner B, Lee RT, Wagers AJ. Restoring Systemic GDF11 Levels Reverses Age-Related Dysfunction in Mouse Skeletal Muscle. Science. 2014;344:649-52.

50. Katsimpardi L, Litterman NK, Schein PA, Miller CM, Loffredo FS, Wojtkiewicz GR, Chen JW, Lee RT, Wagers AJ, Rubin LL. Vascular and neurogenic rejuvenation of the aging mouse brain by young systemic factors. Science. 2014;344:630-4.

51. Chiam JT, Dobson RJ, Kiddle SJ, Sattlecker M. Are blood-based protein biomarkers for Alzheimer's disease also involved in other brain disorders? A systematic review. J Alzheimers Dis. 2015:43:303-14.

52. Walker RG, Poggioli T, Katsimpardi L, Buchanan SM, Oh J, Wattrus S, Heidecker B, Fong YW, Rubin LL, Ganz P, Thompson TB, Wagers AJ, Lee RT. Biochemistry and Biology of GDF11 and Myostatin: Similarities, Differences, and Questions for Future Investigation. Circ Res. 2016;118:1125-41 discussion 42

53. Schafer MJ, Atkinson EJ, Vanderboom PM, Kotajarvi B, White TA, Moore MM, Bruce CJ, Greason KL, Suri RM, Khosla S, Miller JD, Bergen HR 3rd, LeBrasseur NK. Quantification of GDF11 and Myostatin in Human Aging and Cardiovascular Disease. Cell Metab. 2016:23:1207-15.

54. Middeldorp J, Lehallier B, Villeda SA, Miedema SS, Evans E, Czirr E, Zhang H, Luo J, Stan T, Mosher KI, Masliah E, Wyss-Coray T. Preclinical Assessment of Young Blood Plasma for Alzheimer Disease. JAMA Neurol. 2016:73:1325-33.

55. Castellano JM, Mosher Kl, Abbey RJ, McBride AA, James ML, Berdnik D, Shen JC, Zou B, Xie XS, Tingle M, Hinkson IV, Angst MS, Wyss-Coray T. Human umbilical cord plasma proteins revitalize hippocampal function in aged mice. Nature. 2017:544:488-92.

56. Laurin D, David Curb J, Masaki KH, White LR, Launer LJ. Midlife C-reactive protein and risk of cognitive decline: a 31-year follow-up. Neurobiol Aging. 2009:30:1724-7. 
57. Koyama A, O'Brien J, Weuve J, Blacker D, Metti AL, Yaffe K. The role of peripheral inflammatory markers in dementia and Alzheimer's disease: a meta-analysis. J Gerontol A Biol Sci Med Sci. 2013;68:433-40.

58. Kiddle SJ, Sattlecker M, Proitsi P, Simmons A, Westman E, Bazenet C, Nelson SK, Williams S, Hodges A, Johnston C, Soininen H, Kloszewska I, Mecocci P, Tsolaki M, Vellas B, Newhouse S, Lovestone S, Dobson RJ. Candidate blood proteome markers of Alzheimer's disease onset and progression: a systematic review and replication study. J Alzheimers Dis. 2014;38:515-31.

59. Becher B, Spath S, Goverman J. Cytokine networks in neuroinflammation. Nat Rev Immunol. 2017;17:49-59.

60. Rogers J, Cooper NR, Webster S, Schultz J, McGeer PL, Styren SD, Civin WH, Brachova L, Bradt B, Ward P, et al. Complement activation by beta-amyloid in Alzheimer disease. Proc Natl Acad Sci U S A. 1992;89:10016-20.

61. Ray S, Britschgi M, Herbert C, Takeda-Uchimura Y, Boxer A, Blennow K, Friedman LF, Galasko DR, Jutel M, Karydas A, Kaye JA, Leszek J, Miller BL, Minthon L, Quinn JF, Rabinovici GD, Robinson WH, Sabbagh MN, So YT, Sparks DL, Tabaton M, Tinklenberg J, Yesavage JA, Tibshirani R, Wyss-Coray T. Classification and prediction of clinical Alzheimer's diagnosis based on plasma signaling proteins. Nat Med. 2007;13:1359-62.

62. Sattlecker M, Kiddle SJ, Newhouse S, Proitsi P, Nelson S, Williams S, Johnston C, Killick R, Simmons A, Westman E, Hodges A, Soininen H, Kloszewska I, Mecocci P, Tsolaki M, Vellas B, Lovestone S, Dobson RJ. Alzheimer's disease biomarker discovery using SOMAscan multiplexed protein technology. Alzheimers Dement. 2014;10:724-34.

63. Hye A, Riddoch-Contreras J, Baird AL, Ashton NJ, Bazenet C, Leung R, Westman E, Simmons A, Dobson R, Sattlecker M, Lupton M, Lunnon K Keohane A, Ward M, Pike I, Zucht HD, Pepin D, Zheng W, Tunnicliffe A, Richardson J, Gauthier S, Soininen H, Kloszewska I, Mecocci P, Tsolaki M, Vellas B, Lovestone S. Plasma proteins predict conversion to dementia from prodromal disease. Alzheimers Dement. 2014;10:799-807.e2.

64. Lehallier B, Essioux L, Gayan J, Alexandridis R, Nikolcheva T, Wyss-Coray T, Britschgi M. Combined Plasma and Cerebrospinal Fluid Signature for the Prediction of Midterm Progression From Mild Cognitive Impairment to Alzheimer Disease. JAMA Neurol. 2016;73:203-12.

65. Korin B, Ben-Shaanan TL, Schiller M, Dubovik T, Azulay-Debby H, Boshnak NT, Koren T, Rolls A. High-dimensional, single-cell characterization of the brain's immune compartment. Nat Neurosci. 2017; advance online publication.

66. Ziv Y, Ron N, Butovsky O, Landa G, Sudai E, Greenberg N, Cohen H, Kipnis J, Schwartz M. Immune cells contribute to the maintenance of neurogenesis and spatial learning abilities in adulthood. Nat Neurosci. 2006;9:268-75.

67. Ron-Harel N, Segev Y, Lewitus GM, Cardon M, Ziv Y, Netanely D, JacobHirsch J, Amariglio N, Rechavi G, Domany E, Schwartz M. Age-dependent spatial memory loss can be partially restored by immune activation. Rejuvenation Res. 2008;11:903-13.

68. Kipnis J, Cohen H, Cardon M, Ziv Y, Schwartz M. T cell deficiency leads to cognitive dysfunction: implications for therapeutic vaccination for schizophrenia and other psychiatric conditions. Proc Natl Acad Sci U S A. 2004:101:8180-5

69. Filiano AJ, Xu Y, Tustison NJ, Marsh RL, Baker W, Smirnov I, Overall CC, Gadani SP, Turner SD, Weng Z, Peerzade SN, Chen H, Lee KS, Scott MM, Beenhakker MP, Litvak V, Kipnis J. Unexpected role of interferon-gamma in regulating neuronal connectivity and social behaviour. Nature. 2016;535: 425-9.

70. Derecki NC, Cardani AN, Yang CH, Quinnies KM, Crihfield A, Lynch KR, Kipnis J. Regulation of learning and memory by meningeal immunity: a key role for IL-4. J Exp Med. 2010;207:1067-80.

71. Schwartz M, Deczkowska A. Neurological Disease as a Failure of BrainImmune Crosstalk: The Multiple Faces of Neuroinflammation. Trends Immunol. 2016:37:668-79.

72. Balusu S, Brkic M, Libert C, Vandenbroucke RE. The choroid plexuscerebrospinal fluid interface in Alzheimer's disease: more than just a barrier. Neural Regen Res. 2016;11:534-7.

73. Baruch K, Ron-Harel N, Gal H, Deczkowska A, Shifrut E, Ndifon W, MirlasNeisberg N, Cardon M, Vaknin I, Cahalon L, Berkutzki T, Mattson MP, GomezPinilla F, Friedman N, Schwartz M. CNS-specific immunity at the choroid plexus shifts toward destructive Th2 inflammation in brain aging. Proc Natl Acad Sci U S A. 2013;110:2264-9.

74. Kunis G, Baruch K, Rosenzweig N, Kertser A, Miller O, Berkutzki T, Schwartz M. IFN-gamma-dependent activation of the brain's choroid plexus for CNS immune surveillance and repair. Brain. 2013;136:3427-40.
75. Deczkowska A, Baruch K, Schwartz M. Type I/II Interferon Balance in the Regulation of Brain Physiology and Pathology. Trends Immunol. 2016;37: 181-92.

76. Baruch K, Deczkowska A, David E, Castellano JM, Miller O, Kertser A, Berkutzki T, Barnett-Itzhaki Z, Bezalel D, Wyss-Coray T, Amit I, Schwartz M. Aging-induced type I interferon response at the choroid plexus negatively affects brain function. Science. 2014;346:89-93.

77. Keren-Shaul H, Spinrad A, Weiner A, Matcovitch-Natan O, Dvir-Szternfeld R, Ulland TK, David E, Baruch K, Lara-Astaiso D, Toth B, Itzkovitz S, Colonna M, Schwartz M, Amit I. A Unique Microglia Type Associated with Restricting Development of Alzheimer's Disease. Cell 169. 2017;e17:1276-90.

78. Tarasoff-Conway JM, Carare RO, Osorio RS, Glodzik L, Butler T, Fieremans E, Axel L, Rusinek H, Nicholson C, Zlokovic BV, Frangione B, Blennow K, Menard J, Zetterberg H, Wisniewski T, de Leon MJ. Clearance systems in the brain-implications for Alzheimer disease. Nat Rev Neurol. 2015;11:457-70.

79. Cronk JC, Filiano AJ, Louveau A, Marin I, Marsh R, Ji E, Goldman DH, Smirnov I, Geraci N, Acton S, Overall CC, Kipnis J. Peripherally derived macrophages can engraft the brain independent of irradiation and maintain an identity distinct from microglia. J Exp Med. 2018;215:1627.

80. Simard AR, Soulet D, Gowing G, Julien JP, Rivest S. Bone marrow-derived microglia play a critical role in restricting senile plaque formation in Alzheimer's disease. Neuron. 2006;49:489-502.

81. Butovsky O, Kunis G, Koronyo-Hamaoui M, Schwartz M. Selective ablation of bone marrow-derived dendritic cells increases amyloid plaques in a mouse Alzheimer's disease model. Eur J Neurosci. 2007;26:413-6.

82. Prokop S, Miller KR, Drost N, Handrick S, Mathur V, Luo J, Wegner A, WyssCoray T, Heppner FL. Impact of peripheral myeloid cells on amyloid-beta pathology in Alzheimer's disease-like mice. J Exp Med. 2015;212:1811-8.

83. Varvel NH, Grathwohl SA, Degenhardt K, Resch C, Bosch A, Jucker M, Neher $J$ J. Replacement of brain-resident myeloid cells does not alter cerebral amyloid-beta deposition in mouse models of Alzheimer's disease. J Exp Med. 2015:212:1803-9.

84. Ulrich JD, Ulland TK, Colonna M, Holtzman DM. Elucidating the Role of TREM2 in Alzheimer's Disease. Neuron. 2017;94:237-48.

85. Hu N, Tan MS, Yu JT, Sun L, Tan L, Wang YL, Jiang T, Tan L. Increased expression of TREM2 in peripheral blood of Alzheimer's disease patients. J Alzheimers Dis. 2014;38:497-501.

86. Mori Y, Yoshino Y, Ochi S, Yamazaki K, Kawabe K, Abe M, Kitano T, Ozaki Y, Yoshida T, Numata S, Mori T, Iga J, Kuroda N, Ohmori T, S-i U. TREM2 mRNA Expression in Leukocytes Is Increased in Alzheimer's Disease and Schizophrenia. PloS One. 2015;10:e0136835.

87. Ozaki Y, Yoshino Y, Yamazaki K, Sao T, Mori Y, Ochi S, Yoshida T, Mori T, J-i I, S-i U. DNA methylation changes at TREM2 intron 1 and TREM2 mRNA expression in patients with Alzheimer's disease. J Psychiatr Res. 2017;92: $74-80$.

88. Tan YJ, Ng ASL, Vipin A, Lim JKW, Chander RJ, Ji F, Qiu Y, Ting SKS, Hameed S, Lee TS, Zeng L, Kandiah N, Zhou J. Higher Peripheral TREM2 mRNA Levels Relate to Cognitive Deficits and Hippocampal Atrophy in Alzheimer's Disease and Amnestic Mild Cognitive Impairment. J Alzheimers Dis. 2017;58: 413-23

89. Zenaro E, Pietronigro E, Della Bianca V, Piacentino G, Marongiu L, Budui S, Turano E, Rossi B, Angiari S, Dusi S, Montresor A, Carlucci T, Nani S, Tosadori G, Calciano L, Catalucci D, Berton G, Bonetti B, Constantin G. Neutrophils promote Alzheimer's disease-like pathology and cognitive decline via LFA-1 integrin. Nat Med. 2015;21:880-6.

90. Gabbita SP, Johnson MF, Kobritz N, Eslami P, Poteshkina A, Varadarajan S, Turman J, Zemlan F, Harris-White ME. Oral TNFalpha Modulation Alters Neutrophil Infiltration, Improves Cognition and Diminishes Tau and Amyloid Pathology in the 3xTgAD Mouse Model. PLoS One. 2015;10:e0137305.

91. Gagliano SA, Pouget JG, Hardy J, Knight J, Barnes MR, Ryten M, Weale ME. Genomics implicates adaptive and innate immunity in Alzheimer's and Parkinson's diseases. Ann Clin Transl Neurol. 2016:3:924-33.

92. Yokoyama JS, Wang Y, Schork AJ, Thompson WK, Karch CM, Cruchaga C, McEvoy LK, Witoelar A, Chen CH, Holland D, Brewer JB, Franke A, Dillon WP, Wilson DM, Mukherjee P, Hess CP, Miller Z, Bonham LW, Shen J, Rabinovici GD, Rosen HJ, Miller BL, Hyman BT, Schellenberg GD, Karlsen TH, Andreassen OA, Dale AM, Desikan RS, Alzheimer's Disease Neuroimaging I. Association Between Genetic Traits for Immune-Mediated Diseases and Alzheimer Disease. JAMA Neurol. 2016;73:691-7.

93. Spani C, Suter T, Derungs R, Ferretti MT, Welt T, Wirth F, Gericke C, Nitsch $\mathrm{RM}$, Kulic L. Reduced beta-amyloid pathology in an APP transgenic mouse 
model of Alzheimer's disease lacking functional B and T cells. Acta Neuropathol Commun. 2015;3:71.

94. Marsh SE, Abud EM, Lakatos A, Karimzadeh A, Yeung ST, Davtyan H, Fote GM, Lau L, Weinger JG, Lane TE, Inlay MA, Poon WW, Blurton-Jones M. The adaptive immune system restrains Alzheimer's disease pathogenesis by modulating microglial function. Proc Natl Acad Sci U S A. 2016;113:E1316-25.

95. Brynskikh A, Warren T, Zhu J, Kipnis J. Adaptive immunity affects learning behavior in mice. Brain Behav Immun. 2008;22:861-9.

96. Wolf SA, Steiner B, Akpinarli A, Kammertoens T, Nassenstein C, Braun A, Blankenstein T, Kempermann G. CD4-positive T lymphocytes provide a neuroimmunological link in the control of adult hippocampal neurogenesis. J Immunol. 2009;182:3979-84.

97. Gaskin F, Finley J, Fang Q, Xu S, Fu SM. Human antibodies reactive with beta-amyloid protein in Alzheimer's disease. J Exp Med. 1993;177:1181-6.

98. Hyman BT, Smith C, Buldyrev I, Whelan C, Brown H, Tang MX, Mayeux R. Autoantibodies to amyloid-beta and Alzheimer's disease. Ann Neurol. 2001; 49:808-10.

99. Du Y, Dodel R, Hampel H, Buerger K, Lin S, Eastwood B, Bales K, Gao F, Moeller HJ, Oertel W, Farlow M, Paul S. Reduced levels of amyloid betapeptide antibody in Alzheimer disease. Neurology. 2001;57:801-5.

100. Weksler ME, Relkin N, Turkenich R, LaRusse S, Zhou L, Szabo P. Patients with Alzheimer disease have lower levels of serum anti-amyloid peptide antibodies than healthy elderly individuals. Exp Gerontol. 2002;37:943-8.

101. Nath A, Hall E, Tuzova M, Dobbs M, Jons M, Anderson C, Woodward J, Guo Z, Fu W, Kryscio R, Wekstein D, Smith C, Markesbery WR, Mattson MP. Autoantibodies to amyloid beta-peptide (Abeta) are increased in Alzheimer's disease patients and Abeta antibodies can enhance Abeta neurotoxicity: implications for disease pathogenesis and vaccine development. Neuromolecular Med. 2003;3:29-39.

102. Schenk D, Barbour R, Dunn W, Gordon G, Grajeda H, Guido T, Hu K, Huang J, Johnson-Wood K, Khan K, Kholodenko D, Lee M, Liao Z, Lieberburg I, Motter R, Mutter L, Soriano F, Shopp G, Vasquez N, Vandevert C, Walker S, Wogulis M, Yednock T, Games D, Seubert P. Immunization with amyloid[beta] attenuates Alzheimer-disease-like pathology in the PDAPP mouse. Nature. 1999:400:173-7.

103. Lemere CA, Masliah E. Can Alzheimer disease be prevented by amyloid-beta immunotherapy? Nat Rev Neurol. 2010;6:108-19.

104. Wang YJ. Alzheimer disease: Lessons from immunotherapy for Alzheimer disease. Nat Rev Neurol. 2014;10:188-9.

105. Graham W, Bonito-Oliva A, Sakmar TP. Update on Alzheimer's Disease Therapy and Prevention Strategies. Annu Rev Med. 2017;68:413-30.

106. Acharya NK, Nagele EP, Han M, Nagele RG. Autoantibodies: Double Agents in Human Disease. Sci Transl Med. 2013;5:186fs19.

107. Nagele EP, Han M, Acharya NK, DeMarshall C, Kosciuk MC, Nagele RG. Natural lgG autoantibodies are abundant and ubiquitous in human sera, and their number is influenced by age, gender, and disease. PLoS One. 2013;8:e60726.

108. Wang H, Williams D, Griffin J, Saito T, Saido TC, Fraser PE, Rogaeva E, Schmitt-Ulms G. Time-course global proteome analyses reveal an inverse correlation between Abeta burden and immunoglobulin $\mathrm{M}$ levels in the APPNL-F mouse model of Alzheimer disease. PLoS One. 2017;12:e0182844

109. DeMarshall CA, Nagele EP, Sarkar A, Acharya NK, Godsey G, Goldwaser EL, Kosciuk M, Thayasivam U, Han M, Belinka B, Nagele RG. Detection of Alzheimer's disease at mild cognitive impairment and disease progression using autoantibodies as blood-based biomarkers. Alzheimers Dement (Amst). 2016;3:51-62.

110. Sudduth TL, Greenstein A, Wilcock DM. Intracranial injection of Gammagard a human IVIg, modulates the inflammatory response of the brain and lowers Abeta in APP/PS1 mice along a different time course than anti-Abeta antibodies. J Neurosci. 2013;33:9684-92.

111. Counts SE, Ray B, Mufson EJ, Perez SE, He B, Lahiri DK. Intravenous immunoglobulin (IVIG) treatment exerts antioxidant and neuropreservatory effects in preclinical models of Alzheimer's disease. J Clin Immunol. 2014; 34(Suppl 1):S80-5.

112. Du Y, Wei X, Dodel R, Sommer N, Hampel H, Gao F, Ma Z, Zhao L, Oertel WH, Farlow M. Human anti-beta-amyloid antibodies block beta-amyloid fibril formation and prevent beta-amyloid-induced neurotoxicity. Brain 2003;126:1935-9.

113. Togo T, Akiyama H, Iseki E, Kondo H, Ikeda K, Kato M, Oda T, Tsuchiya K, Kosaka K. Occurrence of T cells in the brain of Alzheimer's disease and other neurological diseases. J Neuroimmunol. 2002;124:83-92.
114. Rogers J, Luber-Narod J, Styren SD, Civin WH. Expression of immune system-associated antigens by cells of the human central nervous system: relationship to the pathology of Alzheimer's disease. Neurobiol Aging. 1988; 9:339-49.

115. Itagaki S, McGeer PL, Akiyama H. Presence of T-cytotoxic suppressor and leucocyte common antigen positive cells in Alzheimer's disease brain tissue. Neurosci Lett. 1988;91:259-64.

116. Ferretti MT, Merlini M, Späni C, Gericke C, Schweizer N, Enzmann G, Engelhardt B, Kulic L, Suter T, Nitsch RM. T-cell brain infiltration and immature antigen-presenting cells in transgenic models of Alzheimer's disease-like cerebral amyloidosis. Brain Behav Immuni. 2016;54:211-25.

117. Browne TC, McQuillan K, McManus RM, O'Reilly JA, Mills KH, Lynch MA. IFNgamma Production by amyloid beta-specific Th1 cells promotes microglial activation and increases plaque burden in a mouse model of Alzheimer's disease. J Immunol. 2013;190:2241-51.

118. Monsonego A, Maron R, Zota V, Selkoe DJ, Weiner HL. Immune hyporesponsiveness to amyloid beta-peptide in amyloid precursor protein transgenic mice: implications for the pathogenesis and treatment of Alzheimer's disease. Proc Natl Acad Sci U S A. 2001:98:10273-8.

119. Trieb K, Ransmayr G, Sgonc R, Lassmann H, Grubeck-Loebenstein B. APP peptides stimulate lymphocyte proliferation in normals, but not in patients with Alzheimer's disease. Neurobiol Aging. 1996;17:541-7.

120. Monsonego A, Zota V, Karni A, Krieger Jl, Bar-Or A, Bitan G, Budson AE, Sperling R, Selkoe DJ, Weiner HL. Increased T cell reactivity to amyloid beta protein in older humans and patients with Alzheimer disease. J Clin Invest. 2003:112:415-22.

121. Loewenbrueck KF, Tigno-Aranjuez JT, Boehm BO, Lehmann PV, TaryLehmann M. Th1 responses to beta-amyloid in young humans convert to regulatory IL-10 responses in Down syndrome and Alzheimer's disease. Neurobiol Aging. 2010;31:1732-42.

122. Rosenkranz D, Weyer S, Tolosa E, Gaenslen A, Berg D, Leyhe T, Gasser T, Stoltze L. Higher frequency of regulatory $T$ cells in the elderly and increased suppressive activity in neurodegeneration. J Neuroimmunol. 2007; 188:117-27.

123. Saresella M, Calabrese E, Marventano I, Piancone F, Gatti A, Calvo MG, Nemni R, Clerici M. PD1 negative and PD1 positive CD4+ T regulatory cells in mild cognitive impairment and Alzheimer's disease. J Alzheimers Dis. 2010;21:927-38

124. Torres KC, Araujo Pereira P, Lima GS, Bozzi IC, Rezende VB, Bicalho MA, Moraes EN, Miranda DM, Romano-Silva MA. Increased frequency of T cells expressing IL-10 in Alzheimer disease but not in late-onset depression patients. Prog Neuropsychopharmacol Biol Psychiatry. 2013;47:40-5.

125. Baruch K, Rosenzweig N, Kertser A, Deczkowska A, Sharif AM, Spinrad A, Tsitsou-Kampeli A, Sarel A, Cahalon L, Schwartz M. Breaking immune tolerance by targeting Foxp3(+) regulatory T cells mitigates Alzheimer's disease pathology. Nat Commun. 2015;6:7967.

126. Monsonego A, Imitola J, Petrovic S, Zota V, Nemirovsky A, Baron R, Fisher Y, Owens T, Weiner HL. Abeta-induced meningoencephalitis is IFN-gammadependent and is associated with T cell-dependent clearance of Abeta in a mouse model of Alzheimer's disease. Proc Natl Acad Sci U S A. 2006;103: 5048-53.

127. Fisher Y, Strominger I, Biton S, Nemirovsky A, Baron R, Monsonego A. Th1 polarization of $T$ cells injected into the cerebrospinal fluid induces brain immunosurveillance. J Immunol. 2014;192:92-102.

128. Cao C, Arendash GW, Dickson A, Mamcarz MB, Lin X, Ethell DW. Abetaspecific Th2 cells provide cognitive and pathological benefits to Alzheimer's mice without infiltrating the CNS. Neurobiol Dis. 2009;34:63-70.

129. Dansokho C, Ait Ahmed D, Aid S, Toly-Ndour C, Chaigneau T, Calle V, Cagnard N, Holzenberger M, Piaggio E, Aucouturier P, Dorothee G. Regulatory $T$ cells delay disease progression in Alzheimer-like pathology. Brain. 2016;139:1237-51.

130. Baek H, Ye M, Kang GH, Lee C, Lee G, Choi DB, Jung J, Kim H, Lee S, Kim JS, Lee HJ, Shim I, Lee JH, Bae H. Neuroprotective effects of CD4+CD25+Foxp3 + regulatory T cells in a 3xTg-AD Alzheimer's disease model. Oncotarget. 2016;7:69347-57.

131. Alves S, Churlaud G, Audrain M, Michaelsen-Preusse K, Fol R, Souchet B, Braudeau J, Korte M, Klatzmann D, Cartier N. Interleukin-2 improves amyloid pathology, synaptic failure and memory in Alzheimer's disease mice. Brain. 2017;140:826-42.

132. Yang $H$, Yang $H$, Xie $Z$, Wei L, Bi J. Systemic transplantation of human umbilical cord derived mesenchymal stem cells-educated T regulatory cells 
improved the impaired cognition in AbetaPPswe/PS1dE9 transgenic mice. PLoS One. 2013;8:e69129.

133. Petitto JM, Cushman JD, Huang Z. Effects of Brain-Derived IL-2 Deficiency and the Development of Autoimmunity on Spatial Learning and Fear Conditioning. J Neurol Disord. 2015;3:196.

134. Baruch K, Deczkowska A, Rosenzweig N, Tsitsou-Kampeli A, Sharif AM, Matcovitch-Natan O, Kertser A, David E, Amit I, Schwartz M. PD-1 immune checkpoint blockade reduces pathology and improves memory in mouse models of Alzheimer's disease. Nat Med. 2016;22:135-7.

135. Schwartz M. Can immunotherapy treat neurodegeneration? Science. 2017; 357:254-5.

136. Latta-Mahieu M, Elmer B, Bretteville A, Wang Y, Lopez-Grancha M, Goniot P, Moindrot N, Ferrari P, Blanc V, Schussler N, Brault E, Roudieres V, Blanchard V, Yang ZY, Barneoud P, Bertrand P, Roucourt B, Carmans S, Bottelbergs A, Mertens L, Wintmolders C, Larsen P, Hersley C, McGathey T, Racke MM, Liu L, Lu J, O'Neill MJ, Riddell DR, Ebneth A, Nabel GJ, Pradier L. Systemic immune-checkpoint blockade with anti-PD1 antibodies does not alter cerebral amyloid-beta burden in several amyloid transgenic mouse models. Glia. 2018;66:492-504.

137. Field R, Campion S, Warren C, Murray C, Cunningham C. Systemic challenge with the TLR3 agonist poly I:C induces amplified IFNalpha/beta and IL-1 beta responses in the diseased brain and exacerbates chronic neurodegeneration. Brain Behav Immun. 2010;24:996-1007.

138. Krstic D, Madhusudan A, Doehner J, Vogel P, Notter T, Imhof C, Manalastas A, Hilfiker M, Pfister S, Schwerdel C, Riether C, Meyer U, Knuesel I. Systemic immune challenges trigger and drive Alzheimer-like neuropathology in mice. J Neuroinflammation. 2012;9:151.

139. Perry VH, Holmes C. Microglial priming in neurodegenerative disease. Nat Rev Neurol. 2014;10:217-24.

140. Ide M, Harris M, Stevens A, Sussams R, Hopkins V, Culliford D, Fuller J, Ibbett P, Raybould R, Thomas R, Puenter U, Teeling J, Perry VH, Holmes C. Periodontitis and Cognitive Decline in Alzheimer's Disease. PLoS One. 2016; 11:e0151081.

141. Vasek MJ, Garber C, Dorsey D, Durrant DM, Bollman B, Soung A, Yu J, Perez-Torres C, Frouin A, Wilton DK, Funk K, DeMasters BK, Jiang X, Bowen JR, Mennerick S, Robinson JK, Garbow JR, Tyler KL, Suthar MS, Schmidt RE, Stevens B, Klein RS. A complement-microglial axis drives synapse loss during virus-induced memory impairment. Nature. 2016; 534:538-43

142. Gray F, Scaravilli F, Everall I, Chretien F, An S, Boche D, Adle-Biassette H, Wingertsmann L, Durigon M, Hurtrel B, Chiodi F, Bell J, Lantos P. Neuropathology of early HIV-1 infection. Brain Pathol. 1996;6(1):15.

143. Rosshart SP, Vassallo BG, Angeletti D, Hutchinson DS, Morgan AP, Takeda K, Hickman HD, McCulloch JA, Badger JH, Ajami NJ, Trinchieri G, Pardo-Manuel de Villena F, Yewdell JW, Rehermann B. Wild Mouse Gut Microbiota Promotes Host Fitness and Improves Disease Resistance. Cell. 2017;171:1015-28.

144. Schroeder BO, Backhed F. Signals from the gut microbiota to distant organs in physiology and disease. Nat Med. 2016;22:1079-89.

145. Thion MS, Low D, Silvin A, Chen J, Grisel P, Schulte-Schrepping J, Blecher R, Ulas T, Squarzoni P, Hoeffel G, Coulpier F, Siopi E, David FS, Scholz C, Shihui F, Lum J, Amoyo AA, Larbi A, Poidinger M, Buttgereit A, Lledo PM, Greter M, Chan JKY, Amit I, Beyer M, Schultze JL, Schlitzer A, Pettersson S, Ginhoux F, Garel S. Microbiome Influences Prenatal and Adult Microglia in a SexSpecific Manner. Cell. 2018;172:500-16.

146. Erny D, Hrabe de Angelis AL, Jaitin D, Wieghofer P, Staszewski O, David E, Keren-Shaul H, Mahlakoiv T, Jakobshagen K, Buch T, Schwierzeck V, Utermohlen O, Chun E, Garrett WS, McCoy KD, Diefenbach A, Staeheli P, Stecher B, Amit I, Prinz M. Host microbiota constantly control maturation and function of microglia in the CNS. Nat Neurosci. 2015;18:965-77.

147. Fung TC, Olson CA, Hsiao EY. Interactions between the microbiota, immune and nervous systems in health and disease. Nat Neurosci. 2017;20:145-55.

148. Sampson TR, Debelius JW, Thron T, Janssen S, Shastri GG, Ilhan ZE, Challis C, Schretter CE, Rocha S, Gradinaru V, Chesselet MF, Keshavarzian A, Shannon KM, Krajmalnik-Brown R, Wittung-Stafshede P, Knight R, Mazmanian SK. Gut Microbiota Regulate Motor Deficits and Neuroinflammation in a Model of Parkinson's Disease. Cell. 2016;167:1469-80 e12.

149. Bedarf JR, Hildebrand F, Coelho LP, Sunagawa S, Bahram M, Goeser F, Bork $P$, Wullner U. Functional implications of microbial and viral gut metagenome changes in early stage L-DOPA-naive Parkinson's disease patients. Genome Med. 2017;9:39.
150. Vogt NM, Kerby RL, Dill-McFarland KA, Harding SJ, Merluzzi AP, Johnson SC, Carlsson CM, Asthana S, Zetterberg H, Blennow K, Bendlin BB, Rey FE. 2017. Gut microbiome alterations in Alzheimer's disease. Sci Rep 7: 13537

151. Cattaneo A, Cattane N, Galluzzi S, Provasi S, Lopizzo N, Festari C, Ferrari C, Guerra UP, Paghera B, Muscio C, Bianchetti A, Volta GD, Turla M, Cotelli MS, Gennuso M, Prelle A, Zanetti O, Lussignoli G, Mirabile D, Bellandi D, Gentile S, Belotti G, Villani D, Harach T, Bolmont T, Padovani A, Boccardi M, Frisoni GB, Group I-F. Association of brain amyloidosis with pro-inflammatory gut bacterial taxa and peripheral inflammation markers in cognitively impaired elderly. Neurobiol Aging. 2017:49:60-8,

152. Minter MR, Zhang C, Leone V, Ringus DL, Zhang X, Oyler-Castrillo P, Musch MW, Liao F, Ward JF, Holtzman DM, Chang EB, Tanzi RE, Sisodia SS.

Antibiotic-induced perturbations in gut microbial diversity influences neuroinflammation and amyloidosis in a murine model of Alzheimer's disease. Sci Rep. 2016;6:30028.

153. Harach T, Marungruang N, Duthilleul N, Cheatham V, Mc Coy KD, Frisoni G, Neher JJ, Fak F, Jucker M, Lasser T, Bolmont T. Reduction of Abeta amyloid pathology in APPPS1 transgenic mice in the absence of gut microbiota. Sci Rep. 2017;7:41802

154. Minter MR, Hinterleitner R, Meisel M, Zhang C, Leone V, Zhang X, OylerCastrillo P, Zhang X, Musch MW, Shen X, Jabri B, Chang EB, Tanzi RE, Sisodia SS. Antibiotic-induced perturbations in microbial diversity during post-natal development alters amyloid pathology in an aged APPSWE/PS1DeltaE9 murine model of Alzheimer's disease. Sci Rep. 2017;7:10411.

155. Sharon G, Sampson TR, Geschwind DH, Mazmanian SK. The Central Nervous System and the Gut Microbiome. Cell. 2016;167:915-32.

156. Walker KA, Hoogeveen RC, Folsom AR, Ballantyne CM, Knopman DS, Windham BG, Jack CR Jr, Gottesman RF. Midlife systemic inflammatory markers are associated with late-life brain volume: The ARIC study. Neurology. 2017;89:2262-70.

157. Abuabara K, Azfar RS, Shin DB, Neimann AL, Troxel AB, Gelfand JM. Causespecific mortality in patients with severe psoriasis: a population-based cohort study in the U.K. Br J Dermatol. 2010;163:586-92.

158. Gisondi P, Sala F, Alessandrini F, Avesani V, Zoccatelli G, Beltramello A, Moretto G, Gambina G, Girolomoni G. Mild cognitive impairment in patients with moderate to severe chronic plaque psoriasis. Dermatology. 2014; 228:78-85.

159. MacPherson KP, Sompol P, Kannarkat GT, Chang J, Sniffen L, Wildner ME, Norris CM, Tansey MG. Peripheral administration of the soluble TNF inhibitor XPro1595 modifies brain immune cell profiles, decreases beta-amyloid plaque load, and rescues impaired long-term potentiation in 5XFAD mice. Neurobiol Dis. 2017;102:81-95.

160. Gallardo G, Holtzman DM. Antibody Therapeutics Targeting A $\beta$ and Tau. Cold Spring Harb Perspect Med. 2017;7:a024331.

161. Kayed R, Head E, Thompson JL, McIntire TM, Milton SC, Cotman CW, Glabe CG. Common Structure of Soluble Amyloid Oligomers Implies Common Mechanism of Pathogenesis. Science. 2003;300:486-9.

162. Lesne S, Koh MT, Kotilinek L, Kayed R, Glabe CG, Yang A, Gallagher M, Ashe $\mathrm{KH}$. A specific amyloid-beta protein assembly in the brain impairs memory. Nature. 2006:440:352-7.

163. Britschgi M, Olin CE, Johns HT, Takeda-Uchimura Y, LeMieux MC, Rufibach K, Rajadas J, Zhang H, Tomooka B, Robinson WH, Clark CM, Fagan AM, Galasko DR, Holtzman DM, Jutel M, Kaye JA, Lemere CA, Leszek J, Li G, Peskind ER, Quinn JF, Yesavage JA, Ghiso JA, Wyss-Coray T. Neuroprotective natural antibodies to assemblies of amyloidogenic peptides decrease with normal aging and advancing Alzheimer's disease. Proc Natl Acad Sci U S A. 2009; 106:12145-50.

164. Moir RD, Tseitlin KA, Soscia S, Hyman BT, Irizarry MC, Tanzi RE. Autoantibodies to redox-modified oligomeric Abeta are attenuated in the plasma of Alzheimer's disease patients. J Biol Chem. 2005;280:17458-63.

165. Lee EB, Leng LZ, Zhang B, Kwong L, Trojanowski JQ, Abel T, Lee VM. Targeting amyloid-beta peptide (Abeta) oligomers by passive immunization with a conformation-selective monoclonal antibody improves learning and memory in Abeta precursor protein (APP) transgenic mice. J Biol Chem. 2006;281:4292-9.

166. Hillen H, Barghorn S, Striebinger A, Labkovsky B, Muller R, Nimmrich V, Nolte MW, Perez-Cruz C, van der Auwera I, van Leuven F, van Gaalen M, Bespalov AY, Schoemaker H, Sullivan JP, Ebert U. Generation and therapeutic efficacy of highly oligomer-specific beta-amyloid antibodies. J Neurosci. 2010;30: 10369-79. 
167. Sevigny J, Chiao P, Bussiere T, Weinreb PH, Williams L, Maier M, Dunstan R, Salloway S, Chen T, Ling Y, O'Gorman J, Qian F, Arastu M, Li M, Chollate S, Brennan MS, Quintero-Monzon O, Scannevin RH, Arnold HM, Engber T, Rhodes K, Ferrero J, Hang Y, Mikulskis A, Grimm J, Hock C, Nitsch RM, Sandrock $A$. The antibody aducanumab reduces Abeta plaques in Alzheimer's disease. Nature. 2016;537:50-6.

168. Bacher M, Depboylu C, Du Y, Noelker C, Oertel WH, Behr T, Henriksen G, Behe M, Dodel R. Peripheral and central biodistribution of (111)In-labeled anti-beta-amyloid autoantibodies in a transgenic mouse model of Alzheimer's disease. Neurosci Lett. 2009:449:240-5.

169. Poduslo JF, Curran GL, Berg CT. Macromolecular permeability across the blood-nerve and blood-brain barriers. Proc Natl Acad Sci U S A. 1994;91:5705-9.

170. Watts RJ, Dennis MS. Bispecific antibodies for delivery into the brain. Curr Opin Chem Biol. 2013;17:393-9.

171. Yu YJ, Atwal JK, Zhang Y, Tong RK, Wildsmith KR, Tan C, Bien-Ly N, Hersom M, Maloney JA, Meilandt WJ, Bumbaca D, Gadkar K, Hoyte K, Luk W, Lu Y, Ernst JA, Scearce-Levie K, Couch JA, Dennis MS, Watts RJ. Therapeutic bispecific antibodies cross the blood-brain barrier in nonhuman primates. Sci Transl Med. 2014;6:261ra154.

172. Nisbet RM, Van der Jeugd A, Leinenga G, Evans HT, Janowicz PW, Gotz J. Combined effects of scanning ultrasound and a tau-specific single chain antibody in a tau transgenic mouse model. Brain. 2017;140:1220-30.

173. Burgess A, Dubey S, Yeung S, Hough O, Eterman N, Aubert I, Hynynen K. Alzheimer disease in a mouse model: MR imaging-guided focused ultrasound targeted to the hippocampus opens the blood-brain barrier and improves pathologic abnormalities and behavior. Radiology. 2014;273:736-45.

174. Jordao JF, Thevenot E, Markham-Coultes K, Scarcelli T, Weng YQ, Xhima K, O'Reilly M, Huang Y, McLaurin J, Hynynen K, Aubert I. Amyloid-beta plaque reduction, endogenous antibody delivery and glial activation by braintargeted, transcranial focused ultrasound. Exp Neurol. 2013;248:16-29.

175. Alonso A. Ultrasound-induced blood-brain barrier opening for drug delivery. Front Neurol Neurosci. 2015;36:106-15.

176. McGeer PL, Rogers J, McGeer EG. Inflammation, anti-inflammatory agents and Alzheimer disease: the last 12 years. J Alzheimers Dis. 2006;9:271-6.

177. Int'Veld BA, Ruitenberg A, Hofman A, Launer LJ, van Duijn CM, Stijnen T, Breteler MM, Stricker BH. Nonsteroidal antiinflammatory drugs and the risk of Alzheimer's disease. N Engl J Med. 2001;345:1515-21.

178. Group A-FR. Follow-up evaluation of cognitive function in the randomized Alzheimer's Disease Anti-inflammatory Prevention Trial and its Follow-up Study. Alzheimers Dement. 2015;11:216-25 e1.

179. Andrieu S, Coley N, Lovestone S, Aisen PS, Vellas B. Prevention of sporadic Alzheimer's disease: lessons learned from clinical trials and future directions. Lancet Neurol. 2015;14:926-44.

180. Loeffler DA. Intravenous immunoglobulin and Alzheimer's disease: what now? J Neuroinflammation. 2013;10:70.

181. Dodel R, Rominger A, Bartenstein P, Barkhof F, Blennow K, Forster S, Winter Y, Bach JP, Popp J, Alferink J, Wiltfang J, Buerger K, Otto M, Antuono P, Jacoby M, Richter R, Stevens J, Melamed I, Goldstein J, Haag S, Wietek S, Farlow M, Jessen F. Intravenous immunoglobulin for treatment of mild-tomoderate Alzheimer's disease: a phase 2, randomised, double-blind, placebo-controlled, dose-finding trial. Lancet Neurol. 2013;12:233-43.

182. Relkin N. Clinical trials of intravenous immunoglobulin for Alzheimer's disease. J Clin Immunol. 2014;34(Suppl 1):S74-9.

183. Butchart J, Brook L, Hopkins V, Teeling J, Puntener U, Culliford D, Sharples R, Sharif S, McFarlane B, Raybould R, Thomas R, Passmore P, Perry VH, Holmes C. Etanercept in Alzheimer disease: A randomized, placebo-controlled, double-blind, phase 2 trial. Neurology. 2015;84:2161-8.

184. Boyd TD, Bennett SP, Mori T, Governatori N, Runfeldt M, Norden M, Padmanabhan J, Neame P, Wefes I, Sanchez-Ramos J, Arendash GW, Potter H. GM-CSF upregulated in rheumatoid arthritis reverses cognitive impairment and amyloidosis in Alzheimer mice. J Alzheimers Dis. 2010;21:507-18.

185. Jim HS, Boyd TD, Booth-Jones M, Pidala J, Potter H. Granulocyte Macrophage Colony Stimulating Factor Treatment is Associated with Improved Cognition in Cancer Patients. Brain Disord Ther. 2012:1.

186. Potter H, Woodcock JH, Boyd T, Sillau SH, Bettcher BM, Daniels J, Heffernan K, Gray H. Safety and Efficacy Results from Phase 2 pilot trial of GM-CSF/ Leukine $^{\circledast}$ in mild-tomoderate AD. AAIC. 2017;2017:P38.

187. The Plasma for Alzheimer Symptom Amelioration (PLASMA) Study: Intravenously-Administered Plasma From Young Donors for Treatment of Mild-To-Moderate Alzheimer's Disease (2014-2017). https://clinicaltrials.gov/ ct2/show/NCT02256306.
188. Jay TR, Hirsch AM, Broihier ML, Miller CM, Neilson LE, Ransohoff RM, Lamb BT, Landreth GE. Disease Progression-Dependent Effects of TREM2 Deficiency in a Mouse Model of Alzheimer's Disease. J Neurosci. 2017:37:637-47.

189. Shi Q, Chowdhury S, Ma R, Le KX, Hong S, Caldarone BJ, Stevens B, Lemere CA. Complement $C 3$ deficiency protects against neurodegeneration in aged plaque-rich APP/PS1 mice. Sci Transl Med. 2017;9:eaaf6295.

190. Fu H, Rodriguez GA, Herman M, Emrani S, Nahmani E, Barrett G, Figueroa HY, Goldberg E, Hussaini SA, Duff KE. Tau Pathology Induces Excitatory Neuron Loss, Grid Cell Dysfunction, and Spatial Memory Deficits Reminiscent of Early Alzheimer's Disease. Neuron 93. 2017;e5:533-41.

191. Saito T, Matsuba Y, Mihira N, Takano J, Nilsson P, Itohara S, Iwata N, Saido TC. Single App knock-in mouse models of Alzheimer's disease. Nat Neurosci. 2014;17:661-3.

192. Hong S, Beja-Glasser VF, Nfonoyim BM, Frouin A, Li S, Ramakrishnan S, Merry KM, Shi Q, Rosenthal A, Barres BA, Lemere CA, Selkoe DJ, Stevens B. Complement and microglia mediate early synapse loss in Alzheimer mouse models. Science. 2016;352:712-6.

193. Griciuc A, Serrano-Pozo A, Parrado Antonio R, Lesinski Andrea N, Asselin Caroline N, Mullin K, Hooli B, Choi Se H, Hyman Bradley T, Tanzi Rudolph E. Alzheimer's Disease Risk Gene CD33 Inhibits Microglial Uptake of Amyloid Beta. Neuron. 2013;78:631-43.

194. Venegas C, Kumar S, Franklin BS, Dierkes T, Brinkschulte R, Tejera D, VieiraSaecker A, Schwartz S, Santarelli F, Kummer MP, Griep A, Gelpi E, Beilharz M, Riedel D, Golenbock DT, Geyer M, Walter J, Latz E, Heneka MT. Microgliaderived ASC specks cross-seed amyloid- $\beta$ in Alzheimer's disease. Nature. 2017:552:355.

195. Heneka MT, Kummer MP, Stutz A, Delekate A, Schwartz S, Vieira-Saecker A, Griep A, Axt D, Remus A, Tzeng T-C, Gelpi E, Halle A, Korte M, Latz E, Golenbock DT. NLRP3 is activated in Alzheimer/'s disease and contributes to pathology in APP/PS1 mice. Nature. 2013;493:674-8.

196. Zhou X, Chen Y, Mok KY, Zhao Q, Chen K, Chen Y, Hardy J, Li Y, Fu AKY, Guo Q, Ip NY, Alzheimer's Disease Neuroimaging I. Identification of genetic risk factors in the Chinese population implicates a role of immune system in Alzheimer's disease pathogenesis. Proc Natl Acad Sci U S A. 2018;115:1697706.

197. Sheean RK, McKay FC, Cretney E, Bye CR, Perera ND, Tomas D, Weston RA, Scheller KJ, Djouma E, Menon P, Schibeci SD, Marmash N, Yerbury JJ, Nutt SL, Booth DR, Stewart GJ, Kiernan MC, Vucic S, Turner BJ. Association of Regulatory T-Cell Expansion With Progression of Amyotrophic Lateral Sclerosis: A Study of Humans and a Transgenic Mouse Model. JAMA Neurol. 2018;75:681-9.

198. Sulzer D, Alcalay RN, Garretti F, Cote L, Kanter E, Agin-Liebes J, Liong C, McMurtrey C, Hildebrand WH, Mao X, Dawson VL, Dawson TM, Oseroff C, Pham J, Sidney J, Dillon MB, Carpenter C, Weiskopf D, Phillips E, Mallal S, Peters B, Frazier A, Lindestam Arlehamn CS, Sette A. T cells from patients with Parkinson's disease recognize a-synuclein peptides. Nature. 2017;546: 656-61.

199. Wendeln AC, Degenhardt K, Kaurani L, Gertig M, Ulas T, Jain G, Wagner J, Hasler LM, Wild K, Skodras A, Blank T, Staszewski O, Datta M, Centeno TP, Capece V, Islam MR, Kerimoglu C, Staufenbiel M, Schultze JL, Beyer M, Prinz M, Jucker M, Fischer A, Neher JJ. Innate immune memory in the brain shapes neurological disease hallmarks. Nature. 2018;556:332-8.

200. Louveau A, Smirnov I, Keyes TJ, Eccles JD, Rouhani SJ, Peske JD, Dereck NC, Castle D, Mandell JW, Lee KS, Harris TH, Kipnis J. Structural and functional features of central nervous system lymphatic vessels. Nature. 2015;523:337-41.

201. Iliff JJ, Wang M, Liao Y, Plogg BA, Peng W, Gundersen GA, Benveniste H, Vates GE, Deane R, Goldman SA, Nagelhus EA, Nedergaard M. A paravascular pathway facilitates CSF flow through the brain parenchyma and the clearance of interstitial solutes, including amyloid beta. Sci Transl Med. 2012:4:147ra11.

202. Talbot S, Foster SL, Woolf CJ. Neuroimmunity: Physiology and Pathology. Annu Rev Immunol. 2016;34:421-47.

203. Kipnis J. Immune system: The "seventh sense". J Exp Med. 2018;215:397-8.

204. Pavlov VA, Chavan SS, Tracey KJ. Molecular and Functional Neuroscience in Immunity. Ann Rev Immunol. 2018;36:783-812.

205. Pavlov VA, Tracey KJ. Neural regulation of immunity: molecular mechanisms and clinical translation. Nat Neurosci. 2017;20:156-66.

206. Rosas-Ballina M, Olofsson PS, Ochani M, Valdes-Ferrer SI, Levine YA, Reardon C, Tusche MW, Pavlov VA, Andersson U, Chavan S, Mak TW, Tracey KJ. 
Acetylcholine-synthesizing T cells relay neural signals in a vagus nerve circuit. Science. 2011;334:98-101.

207. Hyman BT, Van Hoesen GW, Damasio AR, Barnes CL. Alzheimer's disease: cell-specific pathology isolates the hippocampal formation. Science. 1984; 225:1168-70.

208. Braak H, Braak E. Neuropathological stageing of Alzheimer-related changes. Acta Neuropathol. 1991;82:239-59.

Ready to submit your research? Choose BMC and benefit from:

- fast, convenient online submission

- thorough peer review by experienced researchers in your field

- rapid publication on acceptance

- support for research data, including large and complex data types

- gold Open Access which fosters wider collaboration and increased citations

- maximum visibility for your research: over $100 \mathrm{M}$ website views per year

At $\mathrm{BMC}$, research is always in progress.

Learn more biomedcentral.com/submissions 